\title{
EL PROTESTANTISMO EN LA ESPAÑA DE LA II REPÚBLICA A LA LUZ DE LOS INFORMES DEL ARCHIVO SECRETO VATICANO
}

\author{
POR \\ José RAMÓn HeRnÁndeZ FigueIREDO \\ Instituto Teológico del «Divino Maestro»-Ourense \\ Instituto Teológico Compostelano
}

\section{RESUMEN}

En vísperas de la Segunda República, una preocupación importante de la Iglesia es el estado y desarrollo del protestantismo en España. Tal preocupación procede directamente del Papa Pío XI que por medio del Secretario de Estado pide al Nuncio Tedeschini un informe exacto y completo de las diversas confesiones cristianas en la Península. Al respecto, son abundantes los datos inéditos que proceden de todas las diócesis españolas.

PALABRAS ClAVE: Tolerancia, Libertad religiosa, Protestantismo, Nunciatura, Iglesia española.

\section{PROTESTANTISM IN SPAIN OF THE II REPUBLIC IN THE LIGHT OF THE REPORTS OF THE VATICAN SECRET ARCHIVES}

\section{ABSTRACT}

On the eve of the Second Republic, an important worry of the Catholic Church is the condition and development of the Protestantism in Spain. Such worry comes directly from the Pope Pio XI that through the Minister asks the Nuncio Tedeschini an exact and complete report about the different Christian confessions in the Iberican Peninsula. About it, there are abundant unpublished information that comes from all the Spanish dioceses.

KEY WORDS: Tolerance, Religious freedom, Protestantism, Nunciature, Spanish church.

Recibido/Received 10-02-2009

Aceptado/Accepted 15-09-2009 


\section{TOLERANCIA Y LIBERTAD RELIGIOSA}

El mensaje bíblico de aceptación y tolerancia hacia los diferentes, los pecadores y los extranjeros no siempre ha recibido idéntica acogida por parte de los mismos cristianos. ${ }^{1}$ Un celo inmoderado por la defensa de la fe o, lo que es peor, una excesiva vinculación con los poderes políticos, los llevaron con frecuencia a sucumbir a la tentación de una intolerancia que no parecía recordar el ejemplo y la doctrina del Señor.

En los albores del humanismo, ya la mística alemana había comenzado a plantar las semillas de la tolerancia, por motivos religiosos. Desde planteamientos filosóficos, la Ilustración hará resurgir con fuerza la idea del principio de la tolerancia, afirmado por Spinoza, Voltaire, Lessing. Pero se puede afirmar que el caldo de cultivo para su nacimiento y su formalización ha sido el ámbito religioso de la Reforma, y más en concreto, el Anglicanismo. La tolerancia como preocupación del pensamiento occidental ha surgido precisamente del mismo Cristianismo, en la medida en que algunas pequeñas comunidades nacidas de la Reforma, trataban de reivindicar un estatuto de legitimidad en los países y regiones en las que los principios seculares se habían convertido también en árbitros de la vida religiosa de sus ciudadanos. Una aportación decisiva a su consolidación se debe a Locke. ${ }^{2}$

Aunque su influencia es notable, hay que esperar a los siglos XVIII y XIX para que el ideal de la tolerancia encuentre su plena expresión en la cultura occidental a través de la proclamación de la libertad de conciencia como uno de los derechos fundamentales del hombre. La Ilustración y el Liberalismo desarrollaron una concepción de la tolerancia basada en la libertad radical del pensamiento y en la relativización de todos los dogmas de las religiones. Por tanto, no resulta extraño que tal pretensión suscitara una viva reacción por parte de la Iglesia católica de finales del siglo XIX. ${ }^{3}$

Con Juan XXIII y el Concilio Vaticano II se afirma el ideal de la tolerancia en el mundo católico. ${ }^{4}$ Sus antecedentes son la renovación de los estudios bíblicos y teológicos, y el diálogo con la filosofía moderna y su reflexión sobre la dignidad de la persona y la primacía de la conciencia. Era el momento de que

\footnotetext{
1 José-Román Flecha AndRÉs, Cristianismo y Tolerancia, Salamanca: Universidad Pontificia de Salamanca, 1996, pp. 18-28.

2 Pedro Bravo Gala, Presentación, en John Locke, Carta sobre la Tolerancia, Madrid 1991, XLII, n. 41.

${ }^{3}$ Recuérdese el llamado «Corpus Politicum Leonianum», que abarca cinco encíclicas del Papa León XIII: Diuturnum illud, 20 junio 1881; Humanum genus, 20 abril 1884; Inmortale Dei, 1 noviembre 1885; Libertas praestantissimum, 20 junio 1888; Sapientiae christianae, 10 enero 1890. Cfr. Georges JARLOT, Doctrine pontificale et histoire, Roma: Pontificia Universidad Gregoriana, 1964.

${ }^{4}$ Cfr. Concilio Vaticano II, Constituciones, Decretos, Declaraciones, Madrid 1966.
} 
la tolerancia, entendida al modo antiguo como un favor nacido de la caridad o de la necesidad política, se viese como defensa del principio de la libertad religiosa. La Gaudium et Spes, del Vaticano II, estableció un modelo nuevo de relaciones con el mundo, basado en el diálogo con todos. ${ }^{5}$

Hay que destacar el decreto conciliar Dignitatis humanae sobre la libertad religiosa. La persona tiene derecho a la libertad religiosa. No debe ser coaccionada para obrar contra su conciencia y actuar contra ella, dentro de los límites debidos. ${ }^{6}$

La tolerancia históricamente va unida a la libertad religiosa. ${ }^{7}$ Salvo durante Sexenio Revolucionario (1868-1874) y la Segunda República (1931-1936), no se ha sancionado constitucionalmente la libertad religiosa. Los protestantes, especialmente los evangélicos, provenientes en su mayoría de Gran Bretaña, Francia y Alemania, procuraron introducir en la Península «su» fe cristiana. Los católicos trataron de defenderse del «veneno» del Protestantismo.

La obra misionera del Protestantismo decimonónico vio en España un objetivo singularmente atractivo al ser un país católico, bastión de una concepción antiprotestante del Cristianismo. Aparte de la British and Foreign Bible Society, en la que la Iglesia Anglicana oficial estaba bien representada, de los calvinistas franceses de París y Pau, y los presbiterianos escoceses de la Spanish Evangelization Society, el principal esfuerzo misionero partió de las iglesias y sectas disidentes del anglicanismo: cuáqueros, Asambleas de Hermanos (más conocidos como Hermanos de Plymouth) y metodistas wesleyanos; y en menor medida de los luteranos alemanes y de los presbiterianos y baptistas norteamericanos. ${ }^{8}$

La reactivación protestante en España coincidió con el reavivamiento religioso conocido por el mundo anglosajón, y los países protestantes en general, a comienzos del siglo XIX. La acción de las sociedades bíblicas y de evangelización fue precedida del extraordinario interés que el mundo hispano despertó en Europa a raíz de su epopeya anti-bonapartista, y por la exhumación de la historia, literatura y tradiciones hispánicas, fuente de inspiración del romanticismo europeo. Gran Bretaña, tan comprometida en el esfuerzo bélico contra Napoleón, sintió mucho interés por España. Lo acreditan el elevado número de visitantes y residentes británicos en territorio hispano, y los numerosos libros ingleses sobre España.

\footnotetext{
${ }^{5}$ Gaudium et Spes, nn. 7b, 21f, 53c, 57f, 59a, 61a.

${ }^{6}$ Dignitatis humanae, nn. 2, 3, 7, 8, 10-12, 14.

${ }^{7}$ Giannino Piana, Tolerancia, en Diccionario Teológico Enciclopédico, Estella 1995, p. 985.

${ }^{8}$ Raymond CARr, Prólogo, en Juan B. VIlar, Intolerancia y libertad en la España contemporánea. Los orígenes del Protestantismo Español actual, Madrid: Istmo, 1994, pp. 11-12.
} 
Las conexiones anglo-españolas se incrementaron desde 1833. La dependencia del régimen liberal isabelino en relación al Reino Unido y Francia, la marcada anglofilia de Espartero y de los progresistas a su paso por el gobierno, la creciente presencia de intereses británicos en España -finanzas, minas, ferrocarriles, servicios, comercio, viticultura-, la afluencia de un elevado número de asesores, técnicos, obreros cualificados, hombres de negocios y simples turistas, reforzaron su influencia. A ello cabe sumar la presencia británica en Gibraltar y la sólida implantación de los intereses británicos en Portugal, cabezas de puente para cualquier tipo de penetración en España. ${ }^{9}$

La unidad religiosa había sido uno de los vectores más destacados y perdurables. Los evangélicos pusieron sus esperanzas en el triunfo en España del liberalismo progresista. Su mejor momento fue la Regencia de Espartero y el Bienio reformador de 1854-1856. Raymond Carr subraya cuán violenta fue la reacción de la Iglesia católica frente a los propagandistas protestantes. La jerarquía eclesiástica contó con el apoyo incondicional de los gobernantes para sofocarla. Eso explica que la implantación protestante en España fuera escasa. ${ }^{10}$

Desde Gibraltar Ruet, Cabrera y Alhama extendieron el protestantismo por Andalucía, Levante y Cataluña, con desiguales resultados. En ese tiempo la Constitución de 1869 aprobó la libertad religiosa. El artículo 21 dice:

«La Nación se obliga a mantener el culto y los ministros de la religión católica. El Ejercicio público o privado de cualquier otro culto queda garantizado a todos los extranjeros residentes en España, sin más limitaciones que las reglas universales de la moral y del derecho. Si algunos españoles profesaren otra religión que la católica, es aplicable a los mismos todo lo dispuesto en el párrafo anterior». ${ }^{11}$

En su entrevista con Prim, Juan Bautista de Cabrera dijo al general:

«Desde hoy en adelante habrá libertad en nuestra patria, verdadera libertad, y concluyó la tiranía. Cada hombre será dueño de su conciencia, y podrá profesar la fe que mejor le parezca. Ustedes pueden volver a su país en el primer vapor que salga, y están en libertad de entrar en España con la Biblia bajo el brazo, y predicar las doctrinas en ella contenidas». .12

\footnotetext{
9 Juan B. VILAR, Intolerancia y libertad en la España contemporánea. Los orígenes del Protestantismo Español actual, o. c., pp. 17-42.

${ }^{10}$ Raymond CARR, Spain, 1808-1939, Oxford 1966, pp. 155-304.

${ }^{11}$ Enrique Tierno GaLVÁn, Leyes políticas españolas fundamentales (1808-1936), Madrid 1972, pp. 123-124.

12 Juan B. VILAR, Intolerancia y libertad en la España contemporánea. Los orígenes del Protestantismo Español actual, o. c., p. 384.
} 
Menéndez Pelayo -que sigue a Balmes- hizo esta rotunda afirmación: el español que ha dejado de ser católico, «es incapaz de creer en cosa alguna. ${ }^{13}$ Es muy revelador que siguiera sosteniéndose muchos años más tarde..$^{14}$

El escaso éxito del proselitismo protestante no es imputable solamente al clero católico y a un ambiente popular hostil. Se debe también a la falta de tacto de los evangelistas extranjeros, que desconocían el medio y la psicología de los españoles. Faltó colaboración y hubo la rivalidad entre las asociaciones que operaban en España. Muchos conversos se inclinaron a la experiencia religiosa intimista, tan lejana a la secular religiosidad exterior de los españoles. Les faltó líderes carismáticos capaces de atraer a las masas, pues Usoz, Ruet y Matamoros no lo fueron, y Borrow y Rule, que poseían más cualidades, eran extranjeros. Hay que reconocer que, con su ejemplo y labor, estimularon al clero católico, sacándolo de su secular sopor y reavivaron el nivel intelectual y la labor pastoral de la Iglesia.

\section{EN TIEMPOS DE Pío XI. El INFORME DEL NUNCIO TEDESCHINI}

Achille Ratti, Papa Pío XI, ha sido definido como el «Papa de la conciliación, de las misiones y de la Acción Católica». Reconcilió a Italia con la Santa Sede, extendió considerablemente la tarea misionera de la Iglesia, y organizó la Acción Católica para la participación y colaboración de los laicos en el apostolado jerárquico de la Iglesia. ${ }^{15}$

La Iglesia afrontó la secularización creciente de la sociedad y la aparición y desarrollo de los regímenes totalitarios. Su pontificado comienza justo han triunfados los comunistas Rusia. Pío XI no se ha dio cuenta del significado de este hecho. Creyó poder negociar, y espero mucho tiempo una «conversión» de Rusia. Fue elegido seis meses antes de la subida al poder de Mussolini, con quien pasará de la fascinación a la protesta cuando la libertad de los fieles y de la Iglesia venga puesta en juego. En los años finales de su pontificado conoció el ascenso del nacionalsocialismo y condenó su ideología racista y pagana. Pío XI publicó treinta encíclicas. ${ }^{16} \mathrm{Su}$ pontificado sucede en el período entre-

${ }^{13}$ Marcelino Menéndez Pelayo, Historia de los Heterodoxos Españoles, Madrid 1956, vol. II, p. 1195 .

14 «No creo que haya posibilidad alguna de pluralismo protestante en España. Los españoles tienden a adherirse a su religión tradicional o a vivir en el agnosticismo lejos de toda religión». Dionisio RIDRUEJo, Spain's Restless Voices, en «Catholic World», mayo 1963, p. 94.

${ }_{15}$ Cfr. Achille Ratti, Pape Pie XI, ed. Ecole Française de Rome. Colloque (15-18 mars 1989: Rome), Rome: Ecole Française de Rome, 1996.

${ }^{16}$ Roger AUBERT, L'insegnamento dottrinale di Pio XI, in Pio XI nel trentesimo della morte (19391969), Milano: Opera diocesana per la preservazione e diffusione della fede, 1969, p. 209. 
guerras (1922-1939). Quise que Cristo reinara y creyó en la eficacia del lema: piedad, estudio, acción. ${ }^{17}$

Preocupó a la Santa Sede la acción protestante en España. Los acuciantes problemas planteados por la llegada de la República rebajaron ese interés. En 1929, mientras languidece lla Dictadura de Primo de Rivera, hay una relativa calma. ${ }^{18}$ Se produjo la oleada misionera proveniente de Europa al acabar la Gran Guerra. La paz la animó.

Con los datos oficiales del Ministerio de Gobernación, el nuncio Federico Tedeschini informó Pietro Gasparri, Secretario de Estado, sobre la propaganda protestante y los medios que para combatirla.

«Eminencia Reverendísima: / Con toda diligencia que la importancia del asunto requiere he hecho una encuesta amplia y detallada acerca: $1^{\circ}$. del estado del Protestantismo en España; $2^{\circ}$. de la eficacia de su propaganda; y $3^{\circ}$. de los medios que podrían emplearse para combatirlo. Para llevar a cabo esta encuesta me he valido de los datos oficiales del Ministerio de Gobernación, de las noticias oficiales transmitidas especialmente para esta encuesta por todos los Prefectos o Gobernadores de las provincias de España, y, además, de datos y noticias recogidas privadamente en cada uno de los puntos en donde existen protestantes.

$1^{\circ}$. La estadística del Protestantismo en España, desde luego, no es alarmante, gracias a Dios, como podrá ver V. Eminencia por la relación que sigue:

Existen en toda España 145 Capillas, 11.227 afiliados a la secta y 78 escuelas con 6.000 alumnos en conjunto. La proporción de afiliados es de uno por cada dos mil, incluidos los de nacionalidad inglesa y alemana que suman un buen número.

Los focos principales se hallan en Madrid ( 2 capillas, 750 afiliados, 10 escuelas con 729 alumnos), Barcelona (13 capillas, 1.075 afiliados y 8 escuelas con 916 alumnos), Tarrasa, provincia de Barcelona y diócesis de Barcelona (6 capillas, 400 afiliados y 4 escuelas con 100 alumnos), Sabadell, provincia y diócesis de Barcelona (3 capillas, 300 afiliados y 4 escuelas con 400 alumnos), Rubí, provincia y diócesis de Barcelona (1 capi1la, 200 afiliados y 1 escuela con 500 alumnos), Figueras, provincia y diócesis de Gerona ( 2 capillas, 433 afiliados y 2 escuelas con 91 alumnos), Lorca, provincia de Murcia y diócesis de Cartagena ( 5 capillas y 2000 afiliados, sin escuelas), Cartagena (5 capillas y 130 afiliados, sin escuelas), Sevilla (2 capillas, 137 afiliados, 2 escuelas con 336 alumnos), Mahón-Mallorca ( 1 capilla, 400 afiliados, 1 escuela con 30 alumnos), Marín, provincia de Pontevedra y diócesis de Santiago (es centro de varios pueblos que en conjunto tiene 7 capillas, 600 afiliados y 4 escuelas con 300 alumnos, el Pastor de Marín tiene categoría de Obispo). En San Sebastián, diócesis de Vitoria, hay 200 afiliados y 1 capilla. Estas ocho provincias y diócesis tienen máxima parte de los protestantes en España. Las otras 40 provincias se hallan, puede decirse, libres de la peste evangélica, excepción hecha de unos pocos en Valencia, Granada, Coruña y Bilbao.

${ }^{17}$ Allocuzione agli allievi del Seminario francese di Roma, 3 gennaio 1935, in Discorsi di Pio XI, Città del Vaticano: Editrice Vaticana, 1985, t. III, p. 252.

${ }^{18}$ Pierre Malerbe, La dictadura en Historia de España, IX: La crisis del Estado: dictadura, república, guerra (1923-1939), ed. Manuel TuÑón DE LARA, Barcelona: Labor, 19872, pp. 9-104. En la dimensión religiosa, cfr. José Manuel Cuenca ToRiBio, ¿Era católica España en 1930?, en Iglesia, Estado y Sociedad en España, 1930-1982, ed. Joaquín RuzZ GimÉNEZ, Barcelona: Argos Vergara, 1984, pp. 25-37.

Hispania Sacra, LXIII

127, enero-junio 2011, 305-371, ISSN: 0018-215-X 
Como se ve, después de tantos años como han transcurrido desde que se rompió en mala hora la Unidad Católica y se estableció la tolerancia de cultos en España, los avances hechos por los protestantes en esta nación no son muy halagadores para ellos; están casi en donde estaban cuando comenzaron, y si se compara el escaso número de adeptos (11.000 contando los alemanes e ingleses) con los esfuerzos, en energías y dinero, que han hecho, el fracaso es evidente. Y es que, como ya hizo notar Balmes, en España el Protestantismo no encuentra ambiente. En España podrá haber irreligiosos, pero no protestantes; el español o no admite ninguna disciplina religiosa o admite la Romana. El Catolicismo tiene hondas raíces de fundamental tradición y la adhesión a la Santa Sede se hace cuestión de honor español. Cambiar la sumisión a la Santa Sede por la sumisión a Lutero, se considera una ridiculez y un absurdo, aun entre los más fríos. Si hacen algunos adeptos son generalmente mujeres llevadas de la curiosidad o por la buena acogida que encuentran sus hijos en las escuelas protestantes.

Claro es que todo esto no significa que se haya de abandonar el campo; ello sería una temeridad. Los protestantes son incansables en sus propagandas, tienen la constancia del espíritu del mal; no se desalientan ante la esterilidad de sus esfuerzos, esperan logran mañana lo que no han podido lograr hoy. Halagan a los incautos con dinero e impresos que dan gratis y esta labor constante y duradera, si no encontrara una oposición enérgica y decidida podría a la larga dar lamentables sorpresas cuyo remedio sería tardío. ${ }^{19}$

$2^{\circ}$. Respecto a la propaganda que hacen es bastante activa; derrochan el dinero que viene principalmente de Londres; pagan bien a los maestros de sus escuelas, exigen cuota muy modesta a sus alumnos, imprimen Biblias y Evangelios que dan poco menos que regalados, esparcen folletos y hasta publican tres periódicos España Evangélica. ${ }^{20} \mathrm{El}$ amigo de la Infancia ${ }^{21}$ y La Torre del Vigía $; 22$ no son por cierto rotativos, son bastante miserables; pero el segundo tiene 2.000 suscripciones. En algunos puntos como en Madrid tienen algo de beneficencia y hasta han abierto un Instituto Evangélico de Teología para preparar futuros Pastores. ${ }^{23}$

Esta Propaganda, con ser constante e intencionada, comparada con el movimiento católico, literario social y político de la Nación, no ocupa sitio entre los elementos de acción, pasa desapercibida; se pasan años sin que un español se dé cuenta de que existen protestantes en España. Esto hace que no haya surgido en España un estado de verdadera polémica doctrinal con los protestantes; sólo de vez en cuando aparece algún folleto contra ellos y algún toque de alerta en los periódicos católicos. No se les concede beligerancia, se les desprecia. Mas este desprecio que en determinadas circunstancias puede ser una buena arma de combate, llevado a la exageración podría traducirse en abandono con provecho de ellos.

${ }^{19}$ Cfr. Sobre «misiones» protestantes, en El Siglo Futuro, año XX, n. 6279, 21 octubre 1927, p. 1.

${ }^{20}$ España Evangélica, año VIII, n. 408, 17 noviembre 1927, en ASV, Arch. Nunz. Madrid, busta 848 , fasc. 4, f. 553. El precio del ejemplar alcanza los 15 céntimos.

${ }^{21}$ El amigo de la Infancia, año LII, n. 9, 1 marzo 1925, en ASV, Arch. Nunz. Madrid, busta 848, fasc. 4 , f. 551 .

${ }^{22}$ La Torre de Vigía, revista mensual, director Eduardo Álvarez Montero. El ejemplar del año I, n. 1, agosto de 1925, en ASV, Arch. Nunz. Madrid, busta 848, fasc. 4, f. 549.

${ }^{23}$ Instituto Evangélico de Teología, noviciado, 3. Madrid. Iglesia del Salvador, edificio en que actualmente y de un modo provisional, se halla instalado este Instituto que durante treinta y siete años funcionó en el Puerto de Santa María, Cádiz. Cfr. ASV, Arch. Nunz. Madrid, busta 848, fasc. 4, ff. 565566, donde aparece la siguiente nota a máquina: «en el curso de 1927, que ha terminado en junio, han tenido cubiertas las 12 plazas de alumnos internos, pero parece que proyectan ampliarlas». 
De aquí que, es mi humilde parecer que, sobre todo en aquellas diócesis en donde radican los focos más intensos y la actividad de los protestantes tiene mayor carácter de agresividad, es de todo punto necesario apercibirse a la defensa y adoptar medidas eficaces para combatirlo.

$3^{\circ}$. Ya los Sres. Obispos, en cuyas diócesis aparece la peste protestante se distinguen por su celo en defender su grey y merecen por ello sinceras alabanzas; cada uno pone en práctica los remedios que le aconseja la realidad. Mas, en general, entre los remedios que pueden adoptarse con resultado, además de la oración, que es siempre el más eficaz, descuellan a mi humilde parecer los siguientes:

a) Aprovechar el arreglo que tienen en España la devoción al Papa y a la Santísima Virgen.

b) No existiendo en España la Unidad Católica, hay que acudir a los remedios que sugiere el celo religioso y la natural resistencia de los españoles al protestantismo, estos dos factores bien aprovechados, sobre todo unidos con traza a los dos anteriormente dichos, pueden hacer imposible la vida del protestantismo en España.

c) Cuando los Gobernadores de provincias son buenos católicos, y lo son casi siempre, los Obispos encuentran en ellos excelente ayuda; pues constituyen aquellos un gran elemento para molestar a los protestantes y hacerles imposible la vida sin necesidad de infringir las leyes del reino o tolerancia religiosa.

d) Misiones en los pueblos donde haya protestantes, hechas éstas por religiosos o sacerdotes preparados para esta clase de luchas, que sepan ridiculizar el protestantismo y presentar las simpatías de la Santa Sede y su acción bienhechora, la eficacia de los sacramentos y pintar con traza el nefando origen del protestantismo en Inglaterra y Alemania. En España no necesitan grandes disertaciones para que el pueblo cobre horror a los protestantes, y los inteligentes ya le tienen juzgado al protestantismo.

e) Procurar que los niños encuentren en nuestras escuelas las ventajas económicas que ofrecen los protestantes. En algunos pueblos como en Loira (Pontevedra, diócesis de Santiago) los niños van a la escuela protestante, porque no hay en el pueblo escuela nacional. Pues bien, aquí procurar abrir una escuela parroquial, por de pronto, y luego hacer que el ayuntamiento cumpla con el deber que le impone el Real Decreto de 23 de diciembre de 1921 de pedir al Estado la construcción de unas Escuelas para las cuales el mismo Estado pague el $80 \%$.

f) Valerse de la Acción Católica de la Mujer para que visiten las casas de los niños o niñas que asisten a las escuelas protestantes, a fin que los retiren. Idem de la Hermandad de la Sagrada Familia que generalmente cuenta con medios más eficaces que la misma Acción Católica. Idem de la Asociación de Padres de Familia, de los Jóvenes propagandistas y de las Juventudes Católicas. Todas estas entidades, si concentran sus esfuerzos en sitiar y hacer el vacío a un foco protestante, si obran aconsejados por el Prelado y dirigidos por el Párroco, pueden fácilmente destruirlo.

g) Difundir folletos en los pueblos infectados, folletos populares por el estilo de los del Padre De Mandato S. J. en Roma, por los años 1890 a 1900.

h) Aprovechar las Conferencias Episcopales. En ellas los Sres. Obispos, en cuyas diócesis hayan aparecido los protestantes, consulten a sus Hermanos los demás Obispos, sobre qué remedios se pueden utilizar y cuáles han utilizado ellos, para combatir con eficacia el Protestantismo.

Estos medios y otros que la necesidad práctica fácilmente sugerirá pueden impedir todo avance del protestantismo en España y aun hacer imposible su vida, por muchos que sean los recursos económicos que reciben del extranjero». ${ }^{24}$

${ }^{24}$ Despacho del nuncio al secretario de Estado, s. f., en ASV, Arch. Nunz. Madrid, busta 848, fasc. 4 , ff. 494-496.

Hispania Sacra, LXIII

127, enero-junio 2011, 305-371, ISSN: 0018-215-X 


\section{CiRCUlAR A LOS OBISPOS}

Pidió el nuncio el 1 de marzo de1930, en una circular a los prelados, de datos exactos y detallados sobre las confesiones protestantes en sus diócesis. Días antes, el 11 de febrero, Eugenio Pacelli sustituyó al Estado el cardenal Gasparri, aunque ya había sido nombrado en su lugar Eugenio Pacelli, que provenía de la Nunciatura de Munich, y ocuparía dicho cargo desde 1929 hasta el año 1939, en que será elegido Papa, con el nombre de Pío XII (1939-1958). He aquí los términos en que se expresa el representante del Papa en España:

«Excelentísimo Señor: / No desconoce seguramente V. E. Rdma. la campaña de propaganda cada día más intensa, y más audaz, que las diversas sectas del Protestantismo, prevaliéndose de sus poderosos medios, máxime económicos, y no obstante, su antigua descomposición y sus tan conocidas diferencias de doctrina y de praxis, vienen desarrollando en todo el mundo, de una manera particular después de la Gran Guerra Europea, como si quisieran compensar con el mayor número de adeptos su falta absoluta de cohesión y de unidad doctrinal y social, e intentaran despojar al Catolicismo de su benéfica influencia y de su divino prestigio.

Esta ofensiva general del Protestantismo no podía menos de alcanzar también a la católica España; y en efecto han querido y quieren hacer presa en ella con tanto más ahínco y empeño, cuanto por su temperamento y por su historia y por lo acendrado de su fe católica y de su devoción a la Santa Sede y a la Virgen Santísima, es España la más reacia a sus propagandas.

El Santo Padre, en el cumplimiento de su divina misión de supremo Pastor de las almas, no puede menos de preocuparse por estas invasiones y acometidas de la herejía; y aunque confía en Dios, que todos estos esfuerzos, por lo que se refiere a la inconmovible fe católica de España serán vanos, desea sin embargo estar enterado de la realidad, importancia y calidad de los peligros que para la fe y la religiosidad de sus hijos Españoles pueda representar la propaganda protestante; y para ello desea conocer con todo detalle por la información de los dignísimos Prelados Españoles, el estado actual del Protestantismo o de cuanto de Protestantismo adolezca en su amadísima España.

Con el fin, pues, de dar a la Santa Sede un completo y concienzudo informe sobre materia de tanto interés para la causa de Dios y de la Iglesia, espero del reconocido celo de V. E. Rvdma. se servirá proporcionarme una relación, la más completa y detallada posible, acerca de la actual situación y desarrollo de la propaganda protestante en esa Diócesis de su muy digno cargo.

Esta relación deberá comprender los siguientes extremos: Si hay Protestantes en la Diócesis; en caso afirmativo, en qué localidades y cuál es su número; si ellos son extranjeros y protestantes de origen, que aquí hayan inmigrado, o, por desgracia, españoles, que lamentablemente apóstatado, aunque solo en lo exterior; desde cuando data su existencia en la localidad; si hay en ella pastores, y, de haberles en qué número; cuál es su procedencia y a qué secta pertenecen; si tienen capilla, y si más de una y con cuáles cultos y prosélitos; si tienen escuelas o colegios, y de tenerlos cuál es la asistencia de niños y alumnos y por qué medios son atraídos; si tienen fundaciones y de qué clase; si tienen asociaciones; cuáles son los medios de propaganda que emplean; y finalmente cuál es la conducta que las Autoridades observan con ellos. A estos extremos hará bien V. E. Rvdma. en añadir todo lo que estime conveniente para dar una idea lo más exacta posible del 
estado del Protestantismo en esa Diócesis; y asimismo se servirá indicar si estima V. E. que sea necesario tomar medidas y cuáles.

Con los sentimientos del más alto aprecio, me es grato reiterarme de Vuestra Excelencia Reverendísima a. y s. s. y afmo. h. / Federico, A. de Lepanto. Nuncio Apostólico. ${ }^{25}$

Los informes de los obispos españoles ilustran todos los aspectos requeridos en la circular Nunciatura y otros varios que los complementan, ayudando a calibrar el estado del Protestantismo en España a comienzos de la Segunda República.

Tedeschini procura responder así a la preocupación del Papa, del cardenal Gasparri, del cardenal Pacelli y de Giuseppe Pizzardo, secretario de la Sagrada Congregación de Asuntos Eclesiásticos Extraordinarios Los datos, incompletos en algunos apartados, como reconoce el mismo nuncio, pero, en sus 115 folios mecanografiados, incluye todas las diócesis españolas, sintetizando las relaciones de sus prelados o vicarios. Lo elaboró entre marzo de 1930 y febrero de 1931 .

«Con fecha 6 de febrero, y distinguido con el n. 4896, tuve el honor de enviar a dicha Secretaría de Estado un particular despacho relativo al Protestantismo en esta Nación. No habiendo recibido ninguna respuesta, y temiendo que un trabajo que me costó tiempo y fatiga se haya extraviado, pido a V. E. que me pueda complacer haciéndome saber si dicho despacho ha llegado a su destino, porque en caso contrario, yo podría disponer que sea enviada otra copia al tratarse de un asunto de mucha importancia para la Iglesia en España». ${ }^{26}$

Respondió a los pocos días monseñor Pizzardo que ha recibido su último despacho del mes de agosto de 1931 pidiendo información sobre el paradero del informe enviado en febrero. Acababa de llegar a la primera sección de la Secretaría de Estado, procedente de la segunda donde se hallaba en estudio. Sin duda, esta tardanza desde el mes de febrero hasta agosto de 1931.27

Publicamos la traducción del texto con las notas a pie de página que informan de la signatura archivística donde se hallan las relaciones sobre el de cada diócesis, los nombres completos de los obispos o vicarios que las prepararon, y la data de su elaboración. Los subrayados son del nuncio Tedeschini.

25 Despacho n. 4345 del nuncio Tedeschini a los obispos de España. Madrid, 1 marzo 1930, en ASV, Arch. Nunz. Madrid, busta 848, fasc. 2, tit. VI, rub. 29, sezione unica, ff. 252-254; otra copia en ASV, A.E.S., Stato Spagna, IV periodo, pos. 790, fasc. 146, anno 1931, Alegato I.

${ }^{26}$ Despacho n. 5157 del nuncio Tedeschini al secretario de la S. C. de Affari Ecclesiastici Straordinari, monseñor Pizzardo. Madrid, 5 agosto 1931, en ASV, A.E.S., Stato Spagna, IV periodo, pos. 790, fasc. 146, anno 1931, f. 4.

27 Despacho del secretario de Affari Ecclesiastici Straordinari al nuncio. Vaticano, 16 agosto 1931, en ASV, Arch. Nunz. Madrid, busta 848, fasc. 3, f. 414. 
La información se ajusta a un patrón para todas las diócesis, conforme al cuestionario enviado en la circular. Sus epígrafes son: protestantes, pastores, capillas, escuelas, asociaciones, fundaciones, propaganda, medios para contrarrestar la propaganda, conducta de las autoridades y resumen de la relación.

La única diócesis de la que no hay referencia en este informe es la de Calahorra y la Calzada, por lo que presento aquí una síntesis de la relación enviada por su obispo: «Logroño, una docena de hombres y una veintena de mujeres; Pradejón, diez familias con un total de 44 adictos. Todos españoles, con un pastor español, el P. Cascante, antes capuchino. Desde hace medio siglo están presentes. Pertenecen a la secta evangélica. En Logroño tienen capilla y escuela en la misma capilla, donde se educan treinta niños; en Pradejón, un colegio mixto, al que asisten 42 niños. Propaganda: hojas, folletos, evangelios y conferencias en su capilla. No consta que existan ni fundaciones ni asociaciones. En cuanto a la actitud de las autoridades, ésta es pasiva y tolerante».28

Este es el informe:

(f. 1) «Eminencia Reverendísima: / Algún año atrás, el Santo Padre, recibiéndome en audiencia, se dignaba informarme sobre el insidioso y perseverante trabajo de penetración que el Protestantismo, por medio de sus innumerables sectas, intenta desde hace años en esta católica nación, y también me entregaba el libro del señor Pfarrer Wilhelm Albrecht titulado «Fünfzig Jahre Evangeliches Deutschtum in Madrid» que se refería a este grave argumento.

Apenas regresado a mi sede, yo me he propuesto comenzar una seria investigación para conseguir datos seguros sobre la importancia y sobre la eficacia de dicha propaganda, y he comenzado a buscar informaciones en los diversos centros que podrían dármela, tanto a los obispos como a aquellos con los que yo he tenido ocasión de hablar, y a cuantas asociaciones católicas, especialmente aquéllas dedicadas a la defensa y a la salvaguarda de la fe, con las cuales me fuera dado ponerme en contacto. Al pronunciar la palabra «protestantismo», todos inmediatamente me respondían que yo tenía razón, que $(f .2)$ el mal era grave y que necesitaba ponerse remedio. Yo entonces pedía rápidamente que me mandaran datos, indicaciones, informaciones, etc. y así me los prometían con toda espontaneidad y cordialidad. Pero pasaba el tiempo, y no venía nadie, o se me respondía que no habían podido encontrar ningún elemento para la deseada respuesta.

Visto que de los nuestros yo no podía conseguir nada, me dirigí hasta el mismo Ministerio de Gobernación, esto es, al Ministerio de los internos; y éste co-

${ }_{28}$ Informe del vicario general de Calahorra-La Calzada, Fernando Bufanda. Calahorra-La Calzada, 13 junio 1930, en ASV, Arch. Nunz. Madrid, busta 848, fasc. 1, n. 9, ff. 32-33. 
rrespondería con rapidez a mi investigación. Pero evidentemente yo no podía darme por contento con aquello poco que el Ministerio me informaba, ni basarme sobre ello.

Visto, por tanto, vana e ineficaz toda otra tentativa, me decidí a conducir yo mismo un estudio adrede, y me dirigí con este fin a los Reverendísimos Ordinarios con una circular (alegato I) ${ }^{29}$ en la que, después de haber reclamado la atención sobre el interés que se debía poner en tan grave problema de la penetración protestante, solicité los siguientes datos: $1^{\circ}$. Número y nacionalidad de los protestantes, lugares donde existen, y fecha de la primera fundación; $2^{\circ}$. Número de los pastores con la procedencia de los mismos y secta a la que pertenecen; $3^{\circ}$. Capillas, cultos que en ellas se celebran y frecuencia de parte $(f .3)$ de los adeptos; $3^{\circ}$. (sic) Escuelas y colegios, número de alumnos y medios de proselitismo; $4^{\circ}$. Fundaciones y asociaciones, sus características; $5^{\circ}$. Medios que se emplean para la propaganda; $6^{\circ}$. Conducta de las Autoridades.

Procuro antes de referir el resultado de este estudio, un resumen histórico sobre la aparición y el desarrollo de los protestantes en España, y sobre la situación jurídica de los mismos después de 1868 en que fue proclamada la libertad religiosa por los revolucionarios, y resumo después fielmente los datos, desgraciadamente con frecuencia superficiales, inciertos y no contrastados, que he podido obtener de los Reverendísimos Ordinarios.

Me parece útil la presentación de los datos arriba expuestos para poder apreciar mejor el valor de las preguntas hechas y las respuestas habidas de seguido a la pregunta. Me permitiré en último lugar el añadir algunas observaciones sobre los datos estadísticos y sobre los medios donde actúa la propaganda sectaria.

\section{Síntesis histórica}

El verdadero período histórico del protestantismo en España se puede decir que comienza con la infausta fecha de la proclamación $(f .4)$ de la libertad religiosa que destruye la unidad católica. Sí existen antes de esta época episodios aislados de tentativas de penetración protestante, sociedades bíblicas que introducen sus publicaciones clandestinamente: cuáqueros, entre ellos el conocido Borrow al que se refiere el obispo de Madrid en su relación, metodistas, etc. que haciendo bases de su ofensiva en el peñón de Gibraltar, repetían una y otra vez las tentativas de penetración, pero sin ningún resultado. No tuvieron éxitos enseguida entre el pueblo, y reclutaron sólo algún intelectual de secundaria importancia y algún sacerdote o religioso apóstata.

La libertad religiosa proclamada en las Juntas Revolucionarias en 1868 abrió las puertas de la nación a los pocos infelices apóstatas que habían llegado

29 Despacho n. 4345 del nuncio Tedeschini a los obispos de España. Madrid, 1 marzo 1930, en ASV, A.E.S., Stato Spagna, IV periodo, pos. 790, fasc. 146, anno 1931.

Hispania Sacra, LXIII

127, enero-junio 2011, 305-371, ISSN: 0018-215-X 
prófugos, y a una cantidad de ministros, pastores vendedores de Biblias. La propaganda comenzó en Andalucía, y fue particularmente intensa en Sevilla. Subvencionado por un centro protestante de los Estados Unidos, aparece allí un señor Nicolás Alonso Marselau, muchacho del Barbero en Gibraltar y antiguo seminarista de Granada. Estos consiguieron reunir entorno a sí un cierto número de religiosos, de sacerdotes apóstatas concubinarios y por fin $(f .5)$ algunos estudiantes de Teología. Entre estos apóstatas estaba el Padre Cabrera, escolapio, que comenzó a publicar la revista titulada «El Evangelio» mientras el dicho Nicolás Alonso publicaba «El Eco del Evangelio». Pero los esfuerzos de aquellos desgraciados cayeron por obra especialmente del señor Mateos Gado que hace surgir el periódico «El Oriente» en el que desenmascaró el grupo de los apóstatas denunciando la conducta inmoral. Así cuando en el año 1870 el Conde de Berndorf fue enviado a la Península Ibérica por los protestantes de Alemania para evangelizar España, debería constatar que «las conquistas del protestantismo eran pocas, o mejor, nulas y que no había ministros cultos que tuvieran influencia en el pueblo».

De hecho, en Cádiz, ciudad la más expuesta por hallarse vecina a Gibraltar, no se abrió ninguna capilla hasta el 1871. En Antequera los protestantes fueron recibidos a pedradas, en Extremadura el párroco de Villanueva de la Vera, Don José García Mora por hurtos con el Vicario Capitular de Plasencia intentó fundar una iglesia liberal cristiana, pero cayó en el ridículo; en Valladolid aparece un Pastor llamado Antonio Carrasco que combatido por los católicos debe escapar a América, muriendo en un naufragio; en León en 1878 un $(f .6)$ ex alumno de Teología llamado Ramón Bon Rodríguez, abrió una capilla y una escuela, pero combatido por el obispo de la diócesis y convencido de sus errores, no sólo abjuró, sino que escribió folletos de propaganda antiprotestante. En Aragón el movimiento fue casi nulo. Por lo que se refiere a Madrid, me remito a cuanto se dice en la relación de su obispo.

Esto en cuanto se refiere a la síntesis histórica, en orden a la cual no se debe omitir la advertencia que resulta muy difícil el presentarla completa, porque los hechos son muy fragmentarios y en la vida de la nación representan sí una pequeña parte que no ha conseguido suscitar un verdadero interés.

\section{Posición jurídica del Protestantismo}

El estudio de esta posición tiene un particular interés en la confrontación con aquello que se refiere a la conducta de la autoridad y para comprender cuáles son los derechos que la ley da a los católicos ante el protestantismo.

La tolerancia religiosa que ponía fin a la feliz era española de la unidad religiosa, fue decretada en el artículo 11 de la constitución de 1876, contrariamente a cuanto establecía el Concordato de 1851 que decía claramente en el $(f .7)$ artículo primero: «excluso quocumque alio cultu». Pero, admitida esta toleran- 
cia, ésa debía entenderse en sentido estricto por obvias razones, y porque así lo declaró Cánovas, autor de la Constitución de 1876, y Silvela en nombre de la Comisión parlamentaria. Incluso el mismo ministro de Estado, esto es, de Exteriores, de entonces, el señor Calderón Collantes, declaró en público Senado que «el artículo 11 de la Constitución no es la libertad de cultos, sino la tolerancia de culto privado».

Pero a pesar de todo esto, el 10 de junio de 1910, con el Ministro Canalejas, se publicó una Real Orden que señala un paso adelante hacia la libertad de culto. Esta Real Orden de Canalejas deroga aquel antecedente de Cánovas del 23 de octubre de 1876, y contra las claras disposiciones constitucionales, autoriza signos religiosos externos que distingan los edificios de las diversas confesiones.

Esta violación de la Constitución desgraciadamente ha tenido siempre más largas aplicaciones y señala la práctica actual. Me gusta, no obstante, recordar como discutiéndose dos años atrás el proyecto del nuevo Código Penal, se ha conseguido cambiar el axioma introducido, «delitos contra la libertad religiosa», en aquella más correspondiente a las normas concordatarias: $(f .8)$ «delitos contra la tolerancia religiosa».

Relaciones de los Reverendísimos Ordinarios.

El estado actual del protestantismo en España ha sido delineado en las relaciones de los Ordinarios cuyos datos me permito referir como me han sido enviados. He de lamentar que especialmente aquellos de los grandes centros sean deficientes, pero en el cómputo global podrán colmar cualquier laguna con datos recibidos de otras partes. En el exponer los datos, he creído conveniente no seguir la división por Provincias Eclesiásticas, ni aquélla por orden alfabético, sino tener sobre todo en cuenta la mayor o menor difusión del Protestantismo en cada una de ellas. Vienen así como primeras aquellas en las cuales el Protestantismo se ha difundido más y donde en recientes reuniones la secta ha recomendado que se intensifique la propaganda, esto es, Madrid, Barcelona, Sevilla, Santiago (en relación especialmente a La Coruña), Mondoñedo (en relación al Ferrol), Cádiz (por Algeciras), Cartagena, Las Palmas, Vitoria (por Bilbao). Siguen después las diócesis en las que el Protestantismo tiene una menor difusión, y por último, aquéllas que, gracias a Dios, están libres de tan grave mal.

\section{(f. 9) Diócesis de Madrid.}

Protestantes. En esta diócesis hay protestantes en Madrid y en El Escorial. Las informaciones recibidas no fijan el número de los mismos ni la nacionalidad. En cuanto al tiempo de existencia, si bien en el 1835 había venido algún cuáquero, y otros se habían sumado en años posteriores, se puede decir que la 
propaganda protestante no se hace de manera pública hasta la época en que, caída la monarquía y triunfando la revolución, las Cámaras no aprobaron la Constitución de 1869 en la que se estableció la libertad de cultos. Puede retenerse esta fecha como aquella del principio de la acción protestante en Madrid.

Pastores. En Madrid hay siete, de los cuales cuatro son alemanes, dos españoles y uno de nacionalidad desconocida. Estos siete son, por así decirlo, de primera categoría, pero debe haber otros de categoría inferior.

Capillas. Existen once: tres pertenecen a la secta evangélica, una a los adventistas, no se sabe cuántas pertenecen a las otras. No consta en qué días celebran los cultos, ni cual es la frecuencia de los mismos.

Escuelas. Poseen doce a las que por desgracia van también los hijos de los católicos, si bien en menor número que aquéllos de los protestantes. (f. 10)

Medios de propaganda. En Madrid publican una revista que se titula «Revista Evangélica» y que tiene mucha circulación. Distribuyen también otras revistas y publicaciones como «El Sembrador» que se publica en México; «El mensajero del Amor de Dios», de California; «Las señales de los tiempos», de Barcelona; «La Torre Vigía» y «España Evangélica», mensuales, de Madrid. Difunden también muchas publicaciones religiosas y venden a precio muy reducido libros, folletos y panfletos. En su librería tienen más de 160 de estas publicaciones. En la Calle de la Flor alta nn. 2 y 4 tiene su sede el centro principal de informaciones que se denomina: «Sociedad de publicaciones religiosas». Merece especial mención la obra titulada «Cincuenta años de vida germanoevangélica en Madrid», escrita en alemán por el sedicente párroco Wilhelm Albrecht, 1864-1914. (Se trata del libro del que una copia, como he dicho al principio, me fue entregada por el Santo Padre).

Acerca de la conducta de las autoridades nada se dice en las informaciones.

Medios que se emplean para contrarrestar la propaganda protestante. A este objeto existen en Madrid la «Obra de la preservación de la fe». Esta obra sigue de cerca $(f .11)$ todos los pasos de los protestantes, y donde éstos fundan una escuela, ésta abre una al lado. De esta manera, ha fundado ya treinta escuelas de niños y niñas, a las que van miles de alumnos.

Existe en Madrid también la «Asociación de Señoras Católicas de Madrid» que se fundó precisamente en la época revolucionaria del 1869 para propagar la enseñanza católica. Sostiene actualmente 54 escuelas, de las que 23 son de niños y 31 de niñas. De estas escuelas, 33 están confiadas a religiosos y religiosas de diversos institutos y en ellos reciben una educación cristiana 10.600 niños. Existen además otras escuelas confiadas a Institutos Religiosos en las que se educan 20.983 pequeños. Faltan todavía muchas escuelas católicas en las que miles de niños abandonados pueden educarse cristianamente y se hallan alejados de la enseñanza herética protestante. 
Con el mismo objeto de contrarrestar la propaganda de los protestantes, en Madrid se constituyó una Junta presidida por un Canónigo de la Catedral. Esta Junta se divide en tres secciones: a) de propaganda, cuyo fin es la traducción y la publicación de las Sagradas Escrituras y de otras obras que se consideren útiles; b) de investigación, cuyo objeto es la búsqueda de todos los datos posibles relativos a la propaganda protestante $(f .12)$ y estudiar los medios para impedirla; c) sección económica, que recoge fondos y los invierte en la publicación de la Sagrada Escritura que distribuye gratis.

El Escorial. Hay protestantes los cuales tienen su sede precisamente en la casa donde vivió por algún tiempo Felipe II, el gran enemigo de los protestantes. La relación no añade nada más.

Cercedilla. En este pueblo los protestantes fundaron algún tiempo atrás una escuela que, sin embargo, no tiene éxito y, por tanto, desapareció. Continúa a vivir allí el pastor por motivos de salud.

Resumen de la diócesis de Madrid. En esta diócesis hay protestantes en Madrid, en El Escorial de abajo y en Cercedilla, pero no se conoce el número. Hay siete pastores, cuatro alemanes, dos españoles y uno de nacionalidad desconocida. Hay once capillas, no se conoce el número de adeptos. Se cuentan doce escuelas, pero no se sabe el número de los alumnos que las frecuentan. Como medio de propaganda se emplea la distribución de publicaciones de diverso género: revistas, folletos y libros, y se publica la «Revista Evangélica» de notable circulación. Toda esta propaganda se combate de parte de los católicos $(f .13)$ con escuelas católicas, bastante numerosas, y con publicaciones, difusión de folletos y libros católicos. ${ }^{30}$

\section{Diócesis de Barcelona.}

En esta diócesis hay protestantes en Barcelona misma, en Rubí, en Horta, en Sabadell, en Badalona y en Tarrasa. No consta en la relación ni el número de los adeptos con que cuenta cada uno de los centros, ni la nacionalidad, ni el tiempo en que tuvieron comienzo.

Pastores. En las informaciones sólo resultan cinco pastores: cuatro en Barcelona y uno en Tarrasa. De los cuatro de Barcelona, tres son españoles, y uno de los mismos es D. Agustín Arenales, sacerdote católico apóstata, que ha sido director de la «Revista Evangélica» o mejor de «España Evangélica». No se sabe de qué nación sea el pastor de Tarrasa. No hay duda de que el número de las capillas y de los centros exige un número superior de ministros y, por tanto, deben ser bastantes extranjeros.

${ }^{30}$ Informe del obispo de Madrid-Alcalá, Leopoldo Eijo y Garay. Madrid, 13 junio 1930, en ASV, Arch. Nunz. Madrid, busta 848, fasc. 1, n. 27, ff. 79-84.

Hispania Sacra, LXIII

127, enero-junio 2011, 305-371, ISSN: 0018-215-X 
Capillas. Hay doce. Evangélico-metodistas, tres; evangélico-adventistas, una; evangélicas, dos, de las que una no recibe ayuda de ningún comité nacional ni extranjero, y se sostiene con los propios medios, manteniendo también la obra en Mataró y San Pol del Mar; presbiteriana, una; evangélico-baptista, otra; (f. 14) de los hermanos evangélicos, dos; anglicana, una; alemana, otra. No se informa de los cultos que se celebran en estas capillas, ni la frecuencia de asistencia a las reuniones.

Escuelas. No se sabe el número. En la relación se dice que son muchas y se mencionan cinco dotadas de un buen claustro docente y de seleccionado material escolástico, instaladas principalmente en los barrios de obreros. La misión metodista es aquella que tiene el mayor número, y está situada en los barrios del Clot y Pueblo nuevo. Se añade que los protestantes han sabido sistematizar bien las cosas porque han destinado a estas escuelas la parte más notable del claustro de profesores, mientras los católicos, por la insuficiencia de profesores, pierden cada día terreno. Se distinguen también por su actividad la secta baptista y presbiteriana.

Existe un Instituto Teológico baptista dirigido por D. V. Leroy David que debe ser extranjero. Los alumnos de este Instituto hacen propaganda en los barrios de Las Cortes de Sansy y en otros de la ciudad. Han obtenido el permiso de acercarse con este fin una vez al mes a Villafranca del Penedés. Cuando en 1925 se estableció este Instituto, los católicos concibieron grandes temores; sin embargo, en el mes de octubre de 1926, se estableció una escuela católica vecina al mismo, dirigida $(f .15)$ por Religiosas, y se deshizo el peligro. Más tarde, esta escuela católica abrió una capilla, y últimamente se ha abierto una escuela nacional que tiene un buen profesor. En la relación no se hace referencia al número de los alumnos de las escuelas protestantes.

Asociaciones y fundaciones. Existe en Barcelona la asociación denominada «Unión Cristiana de Jóvenes», de la que es secretario un suizo. Se dice que se fundó en seguida por medio de dos masones (Gertsche y Carsi), que recibieron el delegado enviado para este fin de la sede internacional de Ginebra.

Medios de propaganda. Además de las predicaciones y las conferencias, emplean la enseñanza en las escuelas y una abundante difusión de estampas de todas las calidades y de todas las formas. De algún tiempo a esta parte un grupo de evangélicos va desarrollando mucha actividad en los barrios de Barcelona. Casi todos los domingos se repite (o se repetía) el espectáculo de bautizar por inmersión en el río Berós o en un canal que atraviesa los barrios. Algunos infelices se dejan seducir. En seguida el pastor dirige un discurso al pueblo, inculcando la idea que ellos cumplen fielmente los preceptos de Cristo que fue bautizado en el Jordán. (f. 16) 
Sectas tituladas del Séptimo Día. En la relación se da noticia sobre esta secta. Se dice que sus adeptos son los más cultos de todos los protestantes de Barcelona. Posee en esta ciudad veinticinco escuelas, capillas y centros. Cuenta con un colegio unido a la estación de Vallvidrera para niños de dos sexos de 10 a 18 años. Son aproximadamente 14 niños internos y otros tantos externos. Cultivan el proyecto de convertirlo en escuela graduada, como dicen aquí. Anunciaron una clase para niños -párvulos-, pero no consiguieron abrirla, porque los católicos instituyeron cerca una escuela gratuita. En el colegio celebran el culto los domingos por la mañana, y procuran atraer a la gente del nuevo barrio que se está formando. Van de casa en casa pidiendo que se manden niños a su Colegio. Tienen el centro principal en la Calle del Consejo de los Cientos. Allí poseen una magnífica capilla con calefacción y con oficios implantados modernamente, con ficheros modernos, con cuatro máquinas de escribir y con cinco o seis empleados. Se dice que intentan fundar un laboratorio de Psicología Experimental, y algunos hospitales implantados científicamente y bien servidos. Estos no serán $(f .17)$ llamados ni laicos, ni protestantes, y no se negará en ellos la entrada al sacerdote, ni al ministro protestante. Se contentan con que de los diez enfermos uno salga convertido a la secta o a la institución.

Pagan también los estudios -preferentemente los de medicina- a algunos jóvenes, con la condición que vayan a estudiar a Suiza para seguir al mismo tiempo los cursos de religión donde consiguen el título de doctor en religión -pastores-. Estos jóvenes quedan luego incondicionalmente adheridos a la secta. La táctica de ésta no está en buscar grandes masas, sino en infiltrar la duda y convencer con la propaganda por medio de libros y folletos. Un solo propagandista de esta secta, en cuatro años, vendió ayudado por treinta hombres asalariados, 127.000 libros sectarios al precio de 15,25 pesetas y hasta de 45 pesetas. Algunos de estos libros tratan de medicina general y no inculcan errores hasta la mitad del libro. No es raro que algunos de estos libros tengan la licencia eclesiástica verdadera o fingida, porque si no se lee todo el libro y con todo cuidado, no se advierte el error. Tanto esta secta como las otras hacen propaganda distribuyendo en cantidad folletos, estampas y libros. Se trata de centenares, de millares de escritos protestantes que se reparten en la $(f .18)$ calle o en las casas.

La capilla Adventista o Evangélico-Adventista publica una revista titulada «Las señales de los tiempos», mensual; la Evangélico-Baptista, «El Eco de la Verdad», mensual; los Hermanos Evangélicos, «El Evangelista», mensual. Todas las capillas de Barcelona que no tienen revista propia reciben y propagan profusamente el semanal de Madrid, «La España Evangélica». Se observa que los centros protestantes de Barcelona están muy cerca de los centros espiritistas, lo que hace sospechar que haya alguna inteligencia o al menos alguna simpatía entre ellos.

Hispania Sacra, LXIII

127, enero-junio 2011, 305-371, ISSN: 0018-215-X 
En las reuniones que el Rotary Club de Barcelona celebró en el Hotel Ritz el 19 de abril de 1927 estuvo presente Mrs. Oliver H. M. Covven, miembro del Comité Mundial de la Young Man Christian Association (YMCA) el cual animó al Rotary Club a colaborar en la implantación en Barcelona de dicha Asociación Cristiana de Jóvenes con aquella finalidad, esto es, el Rotary Club tiene mucha semejanza.

En el informe nada se dice de la conducta de las autoridades. Esto de Barcelona es un caso serio que no se puede $(f .19)$ dejar pasar. Si bien el protestantismo no tiene logrado grandes progresos, todavía continúa a mantener una propaganda intensa, siendo absolutamente necesario que se organice la defensa de la fe católica de forma inteligente y adecuada para anular los efectos de la propaganda protestante. En el curso de la relación se hace constatar que los católicos han abierto escuelas próximas a aquéllas protestantes; sin embargo, estas escuelas no bastan, y resulta necesario establecer otras que, tanto por el personal docente como por el material escolar, no sean inferiores a las escuelas protestantes, e incluso sean superiores. Ya lo dice el mismo Obispo de Barcelona que es necesario procurar la instrucción religiosa del pueblo y de las personas inteligentes en modo del todo particular: es necesario intensificar la enseñanza del Catecismo, sobre todo, en los nuevos y enormes núcleos de población que se están formando en Barcelona, es necesario fundar escuelas católicas junto a las protestantes, es necesario publicar y distribuir profusamente sobre todo más publicaciones que folletos, sean periódicos o no, defendiendo los dogmas atacados por los protestantes y teniendo presentes los errores que divulgan sus periódicos, revistas, publicaciones, folletos. Es necesario hacer públicos los datos concretos del protestantismo en Alemania, en Inglaterra, $(f$. 20) en los Estados Unidos, etc. y de este modo se atacaría directamente a la secta. Se podría también emplear el medio que se adopta en algunas regiones de los Estados Unidos, esto es, publicar en los periódicos por medio de anuncios breves notas apologéticas. Además, se podría ver si convenía atacar directamente a las sectas, descubriendo sus escuelas, sus centros, etc. Sin embargo, esto podría convertirse en un peligro, sirviéndoles de anuncio. Aquello que más importa es infundir en todos los católicos el antiguo horror que los nuestros sentían por el protestantismo. ${ }^{31}$

\section{Diócesis de Sevilla.}

Hay en la misma ciudad de Sevilla de quince a veinte familias protestantes ingleses, una familia holandesa y algunas alemanas. En Almonaster la Real es protestante el personal directivo de la minería que es inglesa; en Alonso, los je-

31 Informe del obispo de Barcelona, José Miralles. Barcelona, 22 marzo 1930, en ASV, Arch. Nunz. Madrid, busta 848, fasc. 1, n. 6, ff. 21-28. 
fes y los altos empleados de las minas, esto es, alrededor de diez familias inglesas que pertenecen a la secta anglicana; en Aznalcóllar, el Director y tres empleados de las minas; en Calañas, cinco familias inglesas, el director y empleados de las minas; en Camas, hay cinco; en Huelva, un centenar, anglicanos, que constituyen la colonia inglesa; en Jerez de la Frontera, cinco familias; en Minas de Río Tinto, algunos anglicanos y presbiterianos ingleses, jefes y empleados ( $f$.21) de las minas; en Puebla de Cazalla, ocho; en Puerto de Santa María, un anglicano y seis presbiterianos; en El Ronquillo, algunos ingenieros suizos; en Sanlúcar de Barrameda, tres; en San Juan de Aznalfarache, dos familias anglicanas; en San Nicolás del Puerto cuatro familias del alto personal de las minas.

Pastores. En Sevilla hay dos, un pastor anglicano y al mismo tiempo maestro; en Huelva uno en Río Tinto, anglicano.

Capillas. Se cuentan dos en Sevilla, una evangélica y otra anglicana. En Huelva, una es poco frecuentada y con poca propaganda oral; en Minas de Río Tinto, una con un pastor que celebra el culto para los anglicanos y para los presbiterianos. En esta capilla primera se hacía mucha propaganda, especialmente escrita, y de allí salían los propagandistas de los centros de Huelva, ahora sin embargo asisten a las reuniones sólo los ingleses de las minas. En el Puerto de Santa María, hay una capilla a la que sólo asisten ocho o diez personas de las familias o dependientes de los propagandistas protestantes.

Escuelas. Hay dos en Sevilla, una en el Barrio de San Roque a la que van alrededor de cien alumnos, y la otra en el Barrio de Omnium Sactorum a la que van cuarenta niños y seis u ocho niñas. La propaganda allí ha sido limitada a las escuelas sin que se extienda ( $f$. 22) al barrio; en Jerez de la Frontera, una con pocos alumnos, y en ella se reparten libros; en Puerto de Santa María, una con veinte o treinta niños que la frecuentan porque dicen los padres (desgraciadamente es verdad) que en ella sus hijos aprenden más que en las escuelas públicas; en Utrera, una de niños con dos maestros, y una de niñas con dos maestras. A cada una de ellas van unos sesenta alumnos de media. Más allá de la enseñanza técnica, todas las tardes hay clase de religión, actos de culto todos los domingos, durante los cuales se insiste mucho en la explicación del Evangelio, especialmente el de San Lucas, y de otros libros del Nuevo Testamento. En la relación no se hace referencia a las asociaciones o fundaciones.

Propaganda. El medio ordinario de propaganda que se emplea, además de aquellos referidos, consiste en la distribución de Biblias, de publicaciones, folletos y revistas editadas en Madrid, como «El amigo de la infancia» y la «España Evangélica». En algunas escuelas regalan también hábitos a los niños. La propaganda en general es poco intensa. Los niños, una vez terminados los cursos, no profesan el protestantismo. 
Medios que se emplean para contrarrestar la propaganda. En Sevilla existe una Asociación del Señor para la fundación y el mantenimiento de escuelas católicas. Actualmente $(f .23)$ sostiene diez muy frecuentadas. También las Conferencias de San Vicente de Paúl, tanto de señoras como de señores, se adaptan para quitar los niños de las escuelas protestantes y conducirlos a las católicas, sean del Estado sean privadas. Sería muy conveniente que en algunos centros de minería de esta diócesis, no hubiera más que escuelas católicas, y que el estado lo exigiera, porque los niños no son protestantes sino bautizados en la Iglesia Católica, si se exceptúan algunos hijos del personal directivo de las minas que en varios centros mineros han venido de otras naciones y son protestantes. Hasta 1913, todas las escuelas mineras eran protestantes, ahora en todas hay maestros católicos, no teniendo parte el pastor.

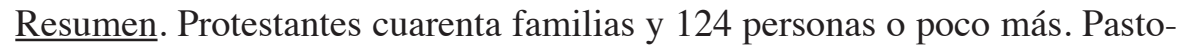
res cuatro, capillas cinco, escuelas cinco con 270 a 300 alumnos. Propaganda se hace distribuyendo revistas, publicaciones, folletos, etc. Asociaciones y fundaciones, no hay. Nada consta en la conducta de las autoridades. Se combate la propaganda con escuelas católicas fundadas por una Asociación de Señoras, con otras fundadas por religiosas y religiosos, con aquellas del Ave María y con centros de beneficencia. ${ }^{32}$

\section{Diócesis de Valencia.}

Protestantes. Hay en la ciudad aproximadamente desde el 1900, pero no (f. 24) se dice ni el número ni la nacionalidad. En Carlet y Sumacarcer, veinticinco de la secta evangélica desde 1880; en Alginet, doce de la misma secta; en Denia, veinticinco anabaptistas desde 1880; en Navarrés, veinticinco desde 1908; en Játiva, seis desde 1918; en Masanasa, una familia desde 1923; en Alcocer, una familia desde 1900. Total, noventa y tres, más dos familias y aquellas residentes en Valencia, ciudad.

Pastores. Hay cinco en Valencia: uno inglés, uno noruego, uno anabaptista y otros dos de los que no se sabe la nacionalidad ni la secta; uno evangelista, en Carlet y Sumacarcer; uno evangelista, en Alginet; uno anabaptista, en Denia; uno evangelista, en Játiva. Total, nueve.

En Valencia existe un colegio con veinticinco alumnos. No se tienen otros datos.

Añade el Arzobispo que hay que agradecer a Dios que en aquella diócesis con más de dos millones de habitantes y con un comercio de exportaciones así

32 Informe del arzobispo de Sevilla, Eustaquio Ilundain y Esteban. Sevilla, 1 mayo 1930, en ASV, Arch. Nunz. Madrid, busta 848, fasc. 1, n. 44, ff. 134-137. 
desarrollado, el protestantismo sea casi insignificante, y que aquello poco que allí hay, esté formado por la colonia extranjera, mientras los protestantes del país no llegan a dos docenas, si bien de vez en cuando se haga propaganda distribuyendo impresos -Evangelios, Biblias principalmente- que, sin embargo, se sorprenden por la buena fe, pues no hacen prosélitos..$^{33}(f .25)$.

\section{Archidiócesis de Santiago de Compostela.}

Protestantes. En Marín hay 62 familias españolas desde 1881. En La Coruña, San José de Ares, Santa María de Lucí, San Martín del Grove y Santo Tomé de Piñeiro hay núcleos de los que no consta el número. En el informe se dice que con estos protestantes y otros diseminados en otros centros se alcanzará el número de 300. No se refiere su nacionalidad.

Pastores. Uno solo inglés en Marín. No consta que haya otros.

Capillas. Una de los evangélicos en Marín. Concurren 180 adeptos. No se sabe que haya otras.

Escuelas. Una mixta, con la frecuencia media de alrededor de cincuenta alumnos. No resulta que haya escuelas en otros centros.

Asociaciones y fundaciones. No hay.

Propaganda. Se sirven de los medios ordinarios difundiendo Biblias, folletos, alguna limosna y propaganda oral. Recorren los países vecinos.

Conducta de las autoridades. Se usa una excesiva tolerancia, si bien últimamente los Gobernadores de La Coruña y Pontevedra habían recibido las indicaciones hechas en esta materia. (f. 26) Gracias a Dios, añade el Arzobispo, la mayor parte de los adeptos al protestantismo no tienen influencia en los oficios públicos, ni entre sus ciudadanos, siendo todos de lamentable conducta moral, conducta que ha sido una de las principales causas que les ha llevado a abrazar el protestantismo. El estado del protestantismo, según el Ordinario, no es inquietante. La propaganda no hace prosélitos, excepto algún caso por problemas más bien personales con el párroco. El clero trabaja con tal celo que se han conseguido conversiones edificantes. Lo que se ha de observar es que el foco principal en aquella diócesis es Marín y que dicho foco ha tenido su origen en la relación que aquellos habitantes han de mantener con la escuadra inglesa, cuyos marinos protestantes se asentaron allí desde hace muchos años por la privilegiadísima posición de la costa del Oeste de España. ${ }^{34}$

${ }^{33}$ Informe del arzobispo de Valencia, Prudencio Melo y Alcalde. Valencia, 1 julio 1930, en ASV, Arch. Nunz. Madrid, busta 848, fasc. 1, n. 56, ff. 160-161.

${ }^{34}$ Informe del arzobispo de Santiago de Compostela, Zacarías Martínez. Núñez. Santiago de Compostela, 5 julio 1930, en ASV, Arch. Nunz. Madrid, busta 848, fasc. 1, n. 41, ff. 126-127. 


\section{Diócesis de Cádiz y Algeciras.}

Protestantes. Hay en Cádiz no más de cien; en Puerto Real un ex pastor; en San Fernando veinticinco o treinta, $(f .27)$ la mayor parte empleados en la Constructora Naval; en Algeciras no se puede decir cuantos son, porque la mayor parte son extranjeros. En La Línea, cien; en Barrios, seis, y en Campamento, tres familias. En total, unos quinientos. La mayor parte son extranjeros y especialmente ingleses. En Cádiz, datan desde el 1868; en San Fernando, desde hace cincuenta años; en Puerto Real, desde hace veinte; en Algeciras, desde hace cincuenta; en La Línea, desde hace cincuenta; en Barrios, desde hace doce; en Campamento, desde hace veinticinco.

Pastores. En Cádiz hay un español que afirma no pertenecer a ninguna secta, en Algeciras hay dos ingleses y anglicanos.

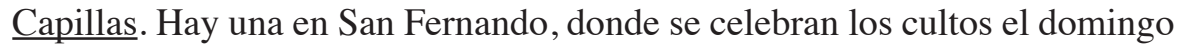
con explicación doctrinal y alrededor de veinte personas; una en Algeciras, en el Hotel María Reina Cristina, para el servicio de los huéspedes protestantes y se celebra el culto generalmente dos veces a la semana, asistiendo en tiempo ordinario, gente necesitada. En los otros lugares las reuniones se tienen en casas particulares: en La Línea, el jueves y el domingo con la asistencia de cincuenta personas; en Barrios una tarde por la semana con cinco o seis adultos, y cincuenta niños de ambos sexos; en Campamento el sábado en una capilla privada y doméstica donde van pocos protestantes de $(f$. 28) origen inglés que allí residen. En Cádiz, no dan ningún signo de vida.

Escuelas. Hay en San Fernando para niños de ambos sexos, con cincuenta o sesenta alumnos; en La Línea, con semejante número de alumnos. Ordinariamente los alumnos son atraídos con regalos.

Asociaciones y fundaciones. No hay. En Cádiz existe un cementerio inglés de propiedad particular donde se sepultan los protestantes de nacionalidad inglesa. Se debió construir probablemente cuando la colonia era más numerosa.

Propaganda. La hacen distribuyendo Biblias y opúsculos, y sobre todo con regalos y limosnas; cesando éstas, cesaría el protestantismo en España.

Conducta de las Autoridades. En general, aquélla impone la tolerancia religiosa. No gozan de un trato de favor. ${ }^{35}$

\section{Diócesis de Ceuta.}

Desde hace pocos años residen en Ceuta algunos protestantes alemanes. No tienen capilla, ni pastor, ni culto, ni escuela, ni maestro, ni fundaciones. Se hace

35 Informe del obispo de Cádiz y administrador apostólico de Ceuta, Marcial López Criado. Cádiz, 20 abril 1930, en ASV, Arch. Nunz. Madrid, busta 848, fasc. 1, n. 8, ff. 30-31. 
mucha propaganda por medio de agentes enviados desde Inglaterra que se dedican a la difusión de Biblias y folletos protestantes. (f.29) El Obispo termina diciendo que en estos últimos años no se ha intensificado la propaganda y que incluso en Cádiz ésta decrece. En San Fernando la situación es estacionaria, y en la misma campaña de Inglaterra no se notan progresos, a no ser la plaza inglesa. Los dos pueblos donde los protestantes podrían hacer mayor daño son Algeciras y La Línea, en ésta por su proximidad a Gibraltar, y en Algeciras por la situación geográfica, por la heterogeneidad de sus habitantes y por sus comunicaciones con Gibraltar. Por estas razones -afirma el Obispo- se está pensando fundar allí una casa religiosa para la enseñanza y la predicación con el fin de contrarrestar la propaganda que se hace desde Gibraltar, y se espera así el poder conseguirlo.

\section{$\underline{\text { Resumen de la diócesis de Cádiz-Ceuta. }}$}

Protestantes: quinientos, la mayor parte extranjeros y especialmente ingleses. Están en Cádiz desde el 1868, en San Fernando desde hace cincuenta años, en Puerto Real desde hace veinte, en Algeciras y La Línea desde hace cincuenta, en Barrios desde hace doce, en Campamento desde hace veinticinco.

Pastores. Tres de los cuales uno es español y los otros dos ingleses.

Capillas. Tres. Asisten a los cultos que se celebran en ellas y en casas particulares alrededor de noventa personas.

Escuelas. Hay cuatro con ciento diez o ciento veinte alumnos de ambos sexos. (f. 30)

Fundaciones o asociaciones. No hay. En Cádiz tienen un cementerio donde se sepultan los protestantes ingleses.

Propaganda. Se hace repartiendo Biblias y otros impresos.

Conducta de las Autoridades. Se sugiere la tolerancia. ${ }^{36}$

Diócesis de Vitoria.

Protestantes. Hay ocho en Bilbao, nueve en Portugalete, y otros, que no se sabe cuantos son, en San Sebastián. Según los datos suministrados por el Cónsul Británico de Bilbao, en Vizcaya hay 550 ingleses de los que 75 son católicos y los otros 475 protestantes. En base a esto puede decirse que en la diócesis de Vitoria hay 493 protestantes, en gran parte ingleses, a parte de aquellos que viven en San Sebastián. No consta cuántos son.

${ }^{36}$ Informe del obispo de Cádiz y administrador apostólico de Ceuta, Marcial López Criado. Cádiz-Algeciras, 20 abril 1930, en ASV, Arch. Nunz. Madrid, busta 848, fasc. 1, n. 8, ff. 30-31. 
Pastores. Hay uno en Bilbao, español, uno en Portugalete, irlandés anglicano, y uno español en San Sebastián.

Capillas. Una en Bilbao en una modestísima casa de alquiler sobre cuya puerta se lee: «Capilla y Escuela Evangélicas». Celebran el culto el domingo y asisten dos o tres mujeres. En Portugalete hay otra capilla y consta que a los cultos no asisten españoles, sino sólo extranjeros. Otra $(f .31)$ capilla está en San Sebastián, pero es apenas conocida y fue frecuentada hasta que la gente no sabía que era protestante. Ahora se celebra un culto semanal al cual van muy pocos, si bien gratifican con una peseta y media a los que van.

Escuelas. Una en Bilbao a la cual van alrededor de cuarenta niños, hijos de comunistas. No existen en Portugalete y en San Sebastián.

Asociaciones o fundaciones. No consta que existan.

Propaganda. En Bilbao y Portugalete no hacen propaganda. Si bien tienen mucho dinero, se limitan a cobrar sus sueldos. En San Sebastián últimamente han difundido algunos folletos anunciando conferencias religiosas que se proponen tener en su capilla, y han publicado en un periódico local un anuncio muy atrayente ofreciendo Biblias en español y en vasco. Pero, es de esperar que no encuentren ambiente en el católico pueblo de San Sebastián y que estas invitaciones caigan en el vacío. Nota el Obispo que por ahora no conviene ocuparse de ellos porque sería darles una importancia que no tienen.

Conducta de las autoridades. Vigilan a los protestantes con perfecta indiferencia. Afortunadamente, concluye el Obispo de $(f .32)$ Vitoria que son muy pocos aquellos que en la diócesis pertenecen al protestantismo.

Resumen. Protestantes, 496, la mayor parte ingleses, no computados aquellos residentes en San Sebastián. Pastores, tres, de los cuales dos españoles y uno irlandés anglicano. Capillas, tres, con poquísima asistencia a los cultos. Escuelas, una en Bilbao con cuarenta alumnos. Asociaciones y fundaciones, no hay. Propaganda: no se hace en Bilbao y Portugalete, en San Sebastián por medio de conferencias. Conducta de las autoridades: de completa indiferencia. ${ }^{37}$

\section{Diócesis de Cartagena.}

Protestantes. Hay 78 en Cartagena, la mayor parte extranjeros ingleses que desde hace cincuenta años tienen a su cargo la Constructora Naval. En Barrio de Peral (antes Los Molinos), cuatro, de los cuales dos extranjeros y dos españoles. Setenta, desde hace 18 años, en San Antón, todos españoles, existen algunos pastores domiciliados en Los Dolores. En Albacete, desde hace treinta años, de ochenta a cien españoles; en Fuenteálamo de Albacete muy pocos, es-

${ }^{37}$ Informe del obispo de Vitoria, Mateo Múgica Urrestarazu. Vitoria, 19 abril 1930, en ASV, Arch. Nunz. Madrid, busta 848, fasc. 1, n. 59, f. 166. 
pañoles, y no se sabe desde cuando; en Hellín-Ontur hay un centro de poca importancia; en Huércal Overa, un español; en Góñar, doce, todos españoles; en Pétrola, cuatro o cinco mujeres de no buena fama; en Águilas, alrededor de trescientos y todos españoles, excepto tres o cuatro de la colonia inglesa, existen desde el tiempo de la construcción de la ferroviaria; en Almendricos, alrededor de cincuenta españoles, desde finales del siglo pasado; en Lorca, $(f .33)$ dos, y en Murcia, alguno, extranjero.

Pastores. Hay siete en Cartagena, todos ingleses. Uno en Albacete de Galicia, uno en Góñar, que se dice pastor, uno en Aguilas y uno en Hellín-Ontur. De estos no consta la nacionalidad.

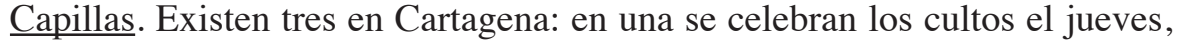
el sábado y el domingo con una treintena de prosélitos; en la otra el martes, el viernes y el domingo con la asistencia de alrededor de veinticinco personas; y en la tercera, el martes y el domingo, mañana y tarde, con alrededor de treinta personas.

En San Antón, se tienen diversas reuniones durante la semana y allí concurren unas setenta personas. No se sabe qué culto se celebra, pero se cree que se trata de instrucciones del pastor. En Ontur, si bien hay capilla, no consta que haya culto. En Almendricos hay dos capillas donde se celebran cultos con lectura de la Biblia. En Albacete, hay una capilla con insignia sobre la puerta, donde se reúnen los protestantes a las doce de cada domingo para la lectura de la Biblia y para la fracción del pan, volviendo a reunirse a las tres de la tarde. Por la mañana va un número mayor de personas. Todas las tardes hay escuela de Sagrada Escritura. En uno de los puntos extremos de la ciudad tienen una estancia destinada para uso de capilla, a la que va poca gente. Tenían otra, pero ha desaparecido por las gestiones de la Acción Católica de la Mujer. (f. 34)

Escuelas. Existen tres en Cartagena, con 33 alumnos, 30 alumnas y 45 niños. En San Antón, hay otra escuela con aproximadamente ocho alumnos de los dos sexos. En Águilas, otra de poca importancia.

Asociaciones y fundaciones. Asociaciones no hay. Sin embargo, hay una fundación de beneficencia en Águilas, pero de poca importancia y prestigio.

Propaganda. Los medios de propaganda son: en Cartagena, venta de libros económicos; en Albacete, distribución de Biblias, folletos y visitas particulares; en Góñar, difusión de hojas, opúsculos y libros; en Águilas, libros y dinero; en Lorca, regalos y Biblias; en Almendricos, libros, hojas y folletos. Actualmente se está tratando de fundar otro centro en Cartagena y se anuncian conferencias para el sábado o el domingo.

Conducta de las Autoridades. Tolerancia o pasividad. En Almansa se ha prohibido la propaganda, y se ha dispuesto prohibirla en Pétrola. 
El Obispo añade que en la diócesis las conversiones del protestantismo al catolicismo son frecuentes, especialmente entre los ingleses y alemanes que habitan aquí. Los Arciprestes afirman que los prosélitos que hace el protestantismo pertenecen a la iglesia más humilde, necesitada e ignorante $(f$. 35) de la sociedad, que va al protestantismo sin convicción y atraída por los beneficios materiales, así como por la facilidad que encuentra donde no hay escuelas católicas. En cuanto a los medios para oponerse a la propaganda protestante se cree que lo mejor es intensificar cuanto sea posible la enseñanza de la doctrina cristiana, y multiplicar los centros de enseñanza religiosa y de beneficencia.

Resumen. Protestantes, seiscientos, algún extranjero y los otros españoles. Pastores, doce, de los cuales son siete ingleses y uno español, no se conoce la nacionalidad de los otros. Capillas, doce. Escuelas, cinco, con 116 alumnos. Fundaciones de beneficencia, una. Propaganda por medio de folletos, hojas, Biblias, regalos, visitas y conferencias. Conducta de las autoridades, meramente pasiva, o de tolerancia. ${ }^{38}$

\section{Diócesis de Mondoñedo.}

Protestantes. Hay cincuenta en el Ferrol, ingleses, empleados en los Arsenales, desde 1909. Cuatro en Ribadeo, españoles pervertidos, desde 1918; cuatro en Benquerencia, esto es, un inglés, y la mujer y las hijas españolas, desde 1922; siete en Villameá, españoles pervertidos por un pastor de Lugo. Total, 65.

Pastores. Uno del Ferrol, pertenece a la secta evangélica $(f .36)$ o anglicana, uno en Benquerencia, hijo del anterior que se dice pastor evangélico sin que conste que lo sea. Total: dos pastores.

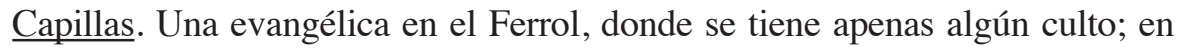
los otros centros no hay capillas, sino un local donde se reúnen un o dos veces a la semana para leer y comentar la Biblia, y cantar salmos. La asistencia a estas reuniones es casi nula, van sólo los interesados y algún curioso. Total una capilla.

Escuelas. Una en el Ferrol, pero sobre todo más de carácter técnico que religioso. La frecuentan los hijos de los ingleses allí residentes.

Asociaciones y fundaciones. No existen.

Medios de propaganda. El más común es la distribución de Biblias, hojas y folletos. Algunas veces se regalan y otras veces se venden en las ferias y en los mercados. Se dan luego conferencias en los locales protestantes, atacando especialmente la confesión, los sufragios y la virginidad y el culto de la Santísima Virgen.

38 Informe del obispo de Cartagena, Vicente Alonso Salgado. Cartagena, 14 junio 1930, en ASV, Arch. Nunz. Madrid, busta 848, fasc. 1, n. 11, ff. 41-44. 
Conducta de las autoridades. Se dice que son excesivamente tolerantes, si bien es cierto que en esta diócesis no hay motivo especial de quejas particulares, aunque en algún caso la autoridad $(f .37)$ ha impedido la venta de Biblias protestantes.

Medios para contrarrestar la propaganda. El más eficaz sería la prohibición de vender o difundir libros o folletos protestantes, pero esto no se puede alcanzar. En tal diócesis dan buen resultado las publicaciones parroquiales o periódicos regionales en que se confutan los errores protestantes y reivindican los dogmas católicos. ${ }^{39}$

\section{Diócesis de Canarias.}

Protestantes. En la ciudad de Las Palmas hay de 300 a 350, casi todos en el Puerto de la Luz, y casi todos extranjeros: ingleses, alemanes y cuatro o cinco noruegos. De los españoles habrá quince o veinte, y su existencia data desde hace cuarenta o cincuenta años.

Pastores. Hay uno inglés, pero no fijo. Está contratado por seis meses y depende del Obispo anglicano de Sierra Leona.

Capillas. Hay una que pertenece a la colonia inglesa, muy amplia y bien adornada, con un gran órgano, situada en la calle Rafael Ramírez de la Ciudad Jardín. Los protestantes ingleses son practicantes de su religión, celebran sus cultos el domingo con lectura de la Biblia, canto de himnos y con aquellos que llaman servicios de comunión y matutino. Los protestantes alemanes hacen sus prácticas en privado.

Escuelas. La colonia alemana tiene un colegio dedicado a la enseñanza elemental de niños y niñas, ingleses y $(f .38)$ alemanes. Entre los profesores hay uno español para la lengua nacional. Lo frecuentan también de veinte a treinta niños españoles para aprender el alemán. En la escuela no se hace propaganda. Como la colonia se compone de personas en su mayor parte ricas, mandan a sus niños a educarse como alumnos internos en los colegios ingleses.

Asociaciones y fundaciones. No parece que más allá de las asociaciones comerciales existan otras. Los protestantes ingleses poseen un cementerio propio en el barrio de S. José.

Tienen también un hospital en el Puerto de la Luz donde se admiten indistintamente protestantes y católicos, pero está reservado sólo a los ingleses o a los que enferman a bordo de los buques ingleses. Está dirigido por un médico inglés protestante y por otro español que no es de hecho practicante. Las enfer-

${ }^{39}$ Informe del obispo de Mondoñedo, Juan José Solís y Fernández. Mondoñedo, 3 mayo 1930, en ASV, Arch. Nunz. Madrid, busta 848, fasc. 1, n. 31, ff. 94 y 96.

Hispania Sacra, LXIII

127, enero-junio 2011, 305-371, ISSN: 0018-215-X 
meras son inglesas, habiendo sido alguna de ellas católica, aunque hoy son todas protestantes. Si entra algún enfermo católico, avisan a la parroquia. Los ingleses tienen en el Puerto de la Luz, calle Albareda, un edificio llamado «Institute» que es el domicilio social del apostolado del mar. Allí van los marinos ingleses y encuentran revistas y libros, juegos y diversiones. Oficialmente no tiene carácter protestante, $(f$. 39) pero, si bien está patrocinado entre otros por el Rey de Bélgica, aquellos que lo frecuentan son protestantes a semejanza del personal. No se hace ninguna propaganda religiosa. Los ingleses tienen también un centro de propaganda en la Isleta, que debe ser subsidiado por la sociedad bíblica. Tienen una casa donde vive una familia española de Tenerife y dos mujeres inglesas protestantes. Allí se reúnen tres días a la semana algunos prosélitos y practican el culto protestante con oraciones, lecturas de la Biblia y explicaciones. También van por las casas para la propaganda, repartiendo Biblias y haciendo invitaciones a sus reuniones. Hasta hace poco tiempo había un centro igual en la calle Franchy Roca, que ahora ha desaparecido. Un año atrás hacían una propaganda mucho más activa y se dedicaban a ella ocho o diez mujeres, pero hoy ésta es muy reducida y son pocos los que asisten a las reuniones. ${ }^{40}$

\section{Diócesis de Tenerife.}

Protestantes. Son pocos núcleos en diversos centros, pero casi todos extranjeros. Los españoles son poquísimos y suelen ser personas educadas en Inglaterra que en la mayor parte de los casos tienen estrechos vínculos familiares con ingleses. Están en Santa Cruz de Tenerife, pero no consta el número ni desde cuando están allí residiendo. En el valle de $(f .40)$ Orotava hay veinticinco ingleses domiciliados, llenándose los hoteles durante el invierno. En Puerto de la Cruz de la Palma hay algunos extranjeros, pero no se sabe cuantos son, y de vez en cuando se ven en Tazacorte, y sobre todo, en Vilaflor, por motivos de salud.

Pastores. Uno en Santa Cruz de Tenerife que se renueva frecuentemente, en general cada seis meses; en Orotava dos, de los que uno ejercita y el otro está jubilado.

Capillas. En Santa Cruz de Tenerife hay allí una y se celebra el culto cada domingo. En Cuaresma también el jueves y el viernes con asistencia de los ingleses que pasan algún tiempo en aquella ciudad. Hay otra en Orotava, que depende del Grand Hotel, donde se celebra el culto dos veces a la semana, para aquellos que pasan el invierno en los hoteles, que en la estación fría están llenos. Durante el resto del año van de dieciocho a veinte, entre los veinticinco protestantes allí domiciliados. En Puerto de la Cruz hay otra capilla, pero en la

40 Informe del obispo de Canarias, Miguel Serra y Sucarrats. Canarias, 17 mayo 1930, en ASV, Arch. Nunz. Madrid, busta 848, fasc. 1, n. 10, ff. 34-38. 
relación no se informa de los cultos que se celebran. Se dice, no obstante, que de los once alemanes protestantes que viven allí, ninguno va a la capilla.

Escuelas. No consta que tengan escuelas. En Puerto de la $(f .41)$ Cruz tienen una biblioteca aneja a la capilla.

Propaganda. No consta que hagan en Santa cruz, ni en otros centros.

Añade el Obispo que no es raro que algunos protestantes ingleses asistan a las funciones en las iglesias católicas y que den ofrendas para las obras parroquiales. Los Directores de las grandes Casas Sociales que suelen ser protestantes, no se ocupan de estas cosas y quizás por política suelen conservar buenas relaciones con los párrocos y también los ayudan especialmente en obras benéficas. Cita también casos de señoras protestantes que envían la servidumbre cada domingo a misa, recomendándole que cumpla con sus deberes religiosos. Nada se dice en la conducta de las autoridades. ${ }^{41}$

\section{Diócesis de Gerona.}

Protestantes. Se hallan en Figueras, aunque también hay otro núcleo en la región. Existen dos sectas, la anglicana y la baptista, pero no consta que tengan adeptos verdaderos. Sólo tienen algunas familias pobres que socorren. Los anglicanos se datan desde 1886, mientras los baptistas son posteriores. No parece que sean españoles. En Vilabertrán, suburbio de Figueras, desde 1890 a 1900 se formó un núcleo de veinte españoles; en Port-Bou, hay uno que se prepara para entrar en la Iglesia Católica; en La Escala, no llegan a veinte y son indignos, datan desde hace mucho tiempo y no están $(f .42)$ bautizados; en Estartit, desde hace treinta años hay dos familias españolas compuestas de ocho o diez personas; en Palafrugell, se hallan algunas mujeres que se dicen protestantes, dos familias que vigilan allí y algún empleado, en total una treintena de personas, todas españolas, excepto las que se acercan a vigilar de origen inglés, datan desde hace muchos años; en Palamós y San Juan de Palamós, que casi forman un solo pueblo, se cuentan cuarenta protestantes entre americanos, alemanes y algunos del mismo pueblo, no bautizan a sus hijos y pertenecen desde hace muchos años a la secta evangélica; en San Feliu de Guixols, siete familias y siete célibes, casi todos de origen alemán, excepto dos célibes que son noruegos, viven allí desde hace muchos años y no se sabe a qué secta pertenecen; en Breda, hay allí una española; en Calella de la Costa, una treintena, un francés y el resto españoles, no consta desde cuanto tiempo existan; en San Pol del Mar, hay desde hace mucho tiempo una familia protestante.

${ }^{41}$ Informe del obispo de Tenerife, Albino González y Menéndez-Reigada. Tenerife, 12 abril 1930, en ASV, Arch. Nunz. Madrid, busta 848, fasc. 1, n. 49, ff. 148-149.

Hispania Sacra, LXIII

127, enero-junio 2011, 305-371, ISSN: 0018-215-X 
Pastores. Hay dos en Figueras, de los que uno es español y el otro de nacionalidad desconocida. Los dos proceden de Inglaterra, uno es anglicano y el otro baptista. Los anglicanos tienen, además del pastor, seis catequistas ingleses. En Palamós, hay otro pastor cuyo origen se ignora.

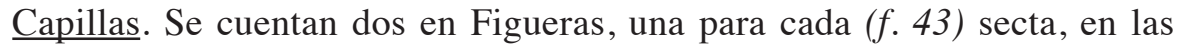
que se celebran los actos de culto con toda publicidad, especialmente por Navidad y por la Semana Santa, épocas en las que se mandan invitaciones a la imprenta. En estos actos se exponen cuadros y se explica la Biblia. En Vilabertrán, hay una capilla en un hermoso edificio que fue de los benedictinos y que los protestantes compraron de un liquidador de bienes eclesiásticos por 1.600 pesetas. No se sabe qué actos de culto se celebran. De cuando en cuando se acerca el pastor de Figueras. En Escala, hay una capilla en la que se celebra el culto, por medio del pastor de Figueras, pero de vez en cuando se acercan con el pastor de Figueras a la casa de un adepto, leen el Evangelio y cantan himnos. En Palafrugell, también hay una capilla, se reúnen en una casa privada, cantan himnos y cumplen otros actos. En Palamós, hay una capilla de los evangelistas, pero no se sabe qué actos de culto se celebran. Atraen a la capilla los niños con imágenes, regalos, meriendas, pero su obra es nula porque ninguno les hace caso. En San Feliu de Guixols, no hay capilla, pero va desde Barcelona el pastor una vez al mes y siempre que es necesario. Sin embargo, los pastores viven muy ocupados en sus asuntos. En Calella de la Costa, $(f .44)$ no hay capilla, se reúnen en ciertos días de la semana en casa de algún adepto, y parece que cantan, leen y escuchan alguna predicación. Están en relación con Barcelona, y quizás algún pastor de esta ciudad va a visitarlos. En marzo del pasado año se ha hecho un funeral protestante de una niña de 14 años.

Escuelas. En Figueras, existe una gratuita para niños con clases diurnas y nocturnas, pero con pocos alumnos. Primero había también una escuela de niñas, pero debería ser cerrada por falta de alumnas. No existen otras escuelas protestantes.

Asociaciones y fundaciones. No existen. Tenían en Figueras una Editorial Bíblica, pero no se sabe si existe todavía o ha desaparecido.

Propaganda. El medio más frecuente y ordinario de propaganda es la difusión de hojas, folletos, libros y particularmente Biblias, regalos a los niños para atraerlos, consistentes en vestidos, juegos. Dan asimismo trajes a los hombres, como en Vilabertrán donde deben tener mucho dinero para la propaganda.

Medios para contrarrestar la propaganda. Hacer propaganda contraria distribuyendo hojas, folletos y libros de sana doctrina antiprotestante. En Figueras se debería abrir $(f .45)$ una escuela gratuita católica para niños pobres y de modes- 
ta condición. Añaden los católicos de Figueras que para quitar los niños de la escuela protestante sería eficaz dar mayor solemnidad a las primeras Comuniones por la gran influencia que ejercen sobre sus padres.

Resumen. Protestantes, 166, de los que 44 son extranjeros, más siete familias extranjeras y otros en Figueras de los que no se sabe el número. Pastores, tres, de los que uno es español y los otros de incierta nacionalidad. Una escuela de niños con pocos alumnos. Propaganda se hace distribuyendo hojas, folletos, Biblias, regalos a los niños y vestidos también a los adultos. No hay asociaciones ni fundaciones. Las autoridades se muestran indiferentes o pasivas. ${ }^{42}$

\section{Diócesis de Orihuela.}

Protestantes. Hay en Alicante y en alguna población no señalada en el informe. No se da el número. Se trata en gran parte de extranjeros, protestantes de origen que han inmigrado a esta diócesis, o de hijos de estos inmigrantes.

Pastores. Actualmente no hay.

Capillas y cultos. Se cuentan dos en la ciudad de Alicante. Celebran el culto el miércoles a las nueve de la noche y el domingo (f.46) a las doce y a las cinco de la tarde. Consiste esto en una ceremonia pseudo-eucarística en la que se distribuye a los asistentes un poco de pan común y vino. Se administra también el así llamado bautismo de San Juan, que alguna vez se celebra en lugares solitarios y otras veces en establecimientos de baño, sobre la playa, o también en otros centros o capillas. El número de los prosélitos que suelen asistir a estos actos ordinariamente es reducido.

Escuelas y asistencias. En Alicante hay tres escuelas protestantes, una llamada Escuela Modelo y otras dos sucursales de la misma en los barrios. La primera tiene aproximadamente 600 alumnos y 200 alumnas, y las otras dos, 200 alumnos. En total, 1.000 alumnos de ambos sexos. Las familias de estos alumnos no pueden ser consideradas como pertenecientes a la secta, pero son personas con gran desarrollo y por algunas ventajas pedagógicas mandan sus hijos a estas escuelas, tanto que muchos de estos mismos niños luego hacen su primera comunión en la Iglesia Católica. Los medios para atraer a los niños a estas escuelas son cuadros pictóricos de hechos bíblicos, pintados en los muros de la Escuela Modelo, que dan a la calle, rótulos como el de la capilla evangélica Bautista, paseos y excursiones de los alumnos por las calles de la ciudad y sus alrededores, con estandartes, pitos y tambores, aunque tal estrépito ya cesó por disposición de la autoridad. $(f .47)$

42 Informe del obispo de Gerona, José Vila Martínez. Gerona, 5 mayo 1930, en ASV, Arch. Nunz. Madrid, busta 848, fasc. 1, n. 17, ff. 58-59.

Hispania Sacra, LXIII

127, enero-junio 2011, 305-371, ISSN: 0018-215-X 
Asociaciones y fundaciones. No consta que existan. Existe un cementerio protestante.

Propaganda. Los medios principales son las conferencias extraordinarias de oradores hechos venir de fuera, hojas, folletos y libros de propaganda escritos en estilo satírico, visitas a casas particulares, fábricas y oficinas, donde los patrones les admiten, envío de revistas como aquella de la Luz del Vigía, venta de vez en cuando de Biblias y libros, si bien en la mayor parte de los casos y de los lugares las autoridades no la permiten.

Conducta de las autoridades. En los lugares donde no viven protestantes, en general las autoridades prestan su apoyo para impedir la propaganda; donde existen, la conducta es de tolerancia, pero no de apoyo. En gran parte todo depende de las circunstancias personales de las autoridades. El Obispo añade que en su diócesis el protestantismo decrece visiblemente y que hay la esperanza de comprar la misma escuela modelo de Alicante, con lo que el protestantismo llegaría a su desaparición.

Medios para contrarrestar la propaganda. Consisten en la intensificación de la enseñanza del catecismo, en la divulgación y defensa de los dogmas y verdades $(f .48)$ de la Iglesia Católica, en la multiplicación de los centros de enseñanza religiosa, dotados de elementos y medios pedagógicos modernos. En Alicante hay fundados colegios de Maristas y Salesianos para niños, y colegios de las Religiosas de Jesús y de María, del Sagrado Corazón y Salesianas del Beato Don Bosco para niñas, dos escuelas del Ave María, un colegio de niñas de las Religiosas de la Compañía de María en localidad vecina a la Escuela Modelo, y otros colegios en los suburbios. Se proyecta también abrir un Instituto de los Padres Escolapios.

Resumen. Hay protestantes en Alicante y en otra población que no se indica. No se dice el número y sólo se anota que no es grande. La mayor parte se trata de extranjeros. Pastores, actualmente no hay. Capillas, dos en Alicante en las cuales se suele celebrar el culto para un pequeño número de adeptos. Escuelas hay tres en Alicante, una llamada Modelo y dos sucursales. Tienen aproximadamente 1.000 alumnos de ambos sexos. Asociaciones y fundaciones no hay. Poseen un cementerio propio. Las autoridades donde no hay protestantes, apoyan que no se haga propaganda; pero donde $(f .49)$ existen, se sigue una línea de tolerancia, pero no de apoyo. La propaganda ordinariamente se hace con cultos, conferencias, difusión y venta de impresos, visitas a casas particulares y establecimientos. ${ }^{43}$

43 Informe del obispo de Orihuela, Javier de Irastorza y Loinaz. Orihuela, abril 1930, en ASV, Arch. Nunz. Madrid, busta 848, fasc. 1, n. 33, ff. 101-109. 


\section{Diócesis de Menorca.}

Protestantes. Hay un grupo de 18 protestantes en Mahón, todos españoles que existen desde el tiempo de la dominación inglesa, reorganizados desde el 1927. Asimismo en Villa Carlos, hay un grupo de 25 desde el tiempo indicado y reorganizados en 1926.

Pastores. Hay uno fijo que tiene dos iglesias, y es metodista. Cada dos meses visita estos centros otro pastor, y un tercero de mayor categoría, cada tres meses. Estos vienen desde Barcelona y generalmente son españoles. Alguna vez envían también alguna misión extraordinaria, como sucede en 1926.

Capillas. Se cuentan dos, evangélicas. Una en la Villa Carlos, desde 1926, y otra en Mahón, desde 1927. Fueron establecidas con autorización de la Delegación del Gobierno de la isla, y como se ve, en pleno período dictatorial. Otras dos son casas particulares, que no se diferencian en nada de las otras. En Mahón van a la capilla sólo el miércoles, y en Villa Carlos $(f$. 50), el jueves y el domingo. Los actos del culto ordinario se reducen a cantar, leer y explicar la Biblia y a la celebración de dos cenas eucarísticas, una el Jueves Santo y otra en Navidad. En el día de la Epifanía tienen la manifestación del DON, que consiste en declarar al pastor de viva voz o por escrito las gracias recibidas durante el año.

Escuelas. Las tuvieron, pero ahora en el presente no las tienen. En Villa Carlos, hay una biblioteca popular.

Asociaciones y fundaciones. Existe una asociación de enfermeros en Villa Carlos, y es de suponer que la tengan también en Mahón. Estas asociaciones curan a los enfermos y les ayudan con una asignación diaria de dos o más pesetas, según el caso. Tienen además una asociación de la buena muerte, que asiste a los moribundos, leen a éstos algunos capítulos de la Biblia, y en caso de muerte los socios se reúnen en la casa del difunto, cantan himnos y el pastor pronuncia un discurso.

Propaganda. La hacen repartiendo Biblias, historias sagradas, hojas y una revista bisemanal titulada «La Buena Nueva». Los folletos los suelen introducir, introduciéndolos debajo de las puertas.

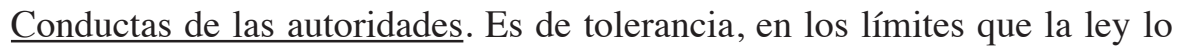
permite.

(f. 51) Dada la circunstancia que las dos capillas surgen en las parroquias más indiferentes e irreligiosas y que reclutan sus adeptos entre gente pobre y que prácticamente no sigue alguna religión, pero que es atraída a la secta metodista más que nada por la utilidad material, se confirma una vez más que en España quien no es católico no tiene ninguna religión. Son mucho más temibles los afiliados a los partidos republicanos, los cuales son absolutamente irreligiosos, y como ya han dicho, puede ser que regresen para mandar en este país. 
Resumen. Hay en Menorca 42 protestantes españoles, probablemente desde el tiempo de la dominación inglesa, un pastor fijo metodista que procede de Barcelona, desde donde vienen periódicamente otros ministros, dos capillas donde se celebran cultos. No hay escuelas, pero sí hay una biblioteca. Tienen dos asociaciones, una para los enfermos y otra de la Buena Muerte. La propaganda se hace repartiendo Biblias, hojas y una revista. La conducta de las autoridades es de tolerancia en los límites de la ley. ${ }^{44}$

\section{Diócesis de Jaén.}

Protestantes. Hay 2.000, en Linares; 100 -colonia minera extranjera-, en El Centenillo; en La Carolina, 250; 100, en Santa Elena; 25, en Baños de la ( $f$. 52) Encina; 50, en Chiclana; 22, en Montizon; 25, en Villanueva del Arzobispo; una o dos familias en Beas, Iznatoraf y Sabiote; 75, en Guarroman; 25, en Úbeda.

Vienen desde el extranjero y especialmente con las sociedades mineras inglesas, belgas y alemanas. Pero actualmente todos son españoles, también el personal dirigente, y entre ellos hay algún sacerdote apóstata. Su existencia en Linares, La Carolina, El Centenillo, Baños de Guarroman es antigua; de hecho la organización actual data del siglo pasado. Chiclana y Montizon, por el contrario, tienen una organización más reciente, aquélla de Villanueva del Arzobispo y de Úbeda data de hace dos años.

Pastores. Hay dos en Linares, uno en La Carolina, uno en Santa Elena, uno en Centenillo. Son españoles, y por la propaganda, el proselitismo y por la instrucción se sirven de señoritas, por lo más inglesas. Hay tres sectas, pero no se sabe sobre cuántos son.

Capillas. Son también escuelas. Hay seis en Linares, dos en La Carolina, una en construcción en Úbeda. Los cultos son bisemanales por regla general y consisten en lecturas, en discursos del pastor y en algunos cantos. Donde no hay capilla o escuela se reúnen en casas particulares. Asiste a los (f. 53) cultos la cuarta parte de los adeptos.

Escuelas. Además de las ya dichas, hay una en Centenillo. Son todas de primera enseñanza, excepto aquélla de La Carolina que es para jóvenes y se dedica especialmente a la enseñanza profesional. En Linares, los alumnos van desde 150 a 200, menos en El Centenillo. Los niños son atraídos con regalos.

Propaganda. Los medios de propaganda que emplean son la difusión de las Biblias y folletos en gran número. Por esto hay en Linares un centro organizado de propaganda, pagado espléndidamente por las sociedades bíblicas extranje-

44 Informe del obispo de Menorca, Antonio Cardona Riera. Menorca, 29 marzo 1930, en ASV, Arch. Nunz. Madrid, busta 848, fasc. 1, n. 30, ff. 92-93. 
ras. Practican también la visita a los enfermos que socorren con dones, con frecuencia no exiguos.

Asociaciones y fundaciones. No existen.

Autoridades. La conducta que las autoridades tienen con los protestantes es de benévola tolerancia. En Chiclana, se les permite ocupar cargas en el municipio, como aquéllas de alcalde y consejero. En esta diócesis -dice el Obispo- el protestantismo no es un resultado de convicciones, sino de conveniencias por los beneficios que aporta a los adeptos.

Medios para contrarrestar la propaganda. En esta diócesis, se ha creado una parroquia nueva en Linares en $(f$. 54$)$ el barrio más pobre y se ha dado desarrollo al Catecismo. Sería conveniente que las autoridades prestasen su ayuda a los párrocos.

Resumen. Protestantes en la diócesis, 2.680. Pastores, cinco españoles. Capillas-escuelas, nueve. Escuelas, una. Asistencia a ellas: de 150 a 200 alumnos en Linares. A los cultos asiste la cuarta parte de los adeptos. Hay tres sectas distintas. Señoritas extranjeras ayudan a los pastores. Propaganda: se hace difundiendo impresos, y con visitas y limosnas a los interesados. Las autoridades observan una actitud de benévola transigencia. ${ }^{45}$

\section{Diócesis de Tuy.}

Protestantes. Se cuentan 150 en Vigo, desde hace treinta años. De ellos, una parte está compuesta por extranjeros empleados en el compañía telegráfica inglesa y en los consulados, los otros son españoles y se dicen evangélicos. En Trasmañó desde hace 18 años hay 25 , todos españoles, pertenecientes a los evangélicos; en Morgadanes, desde hace 80 años, cuatro, todas mujeres; en Sotomayor, desde hace treinta años, cuatro familias anglicanas; en Camposancos, una familia compuesta de madre y tres hijas, pertenecientes a la secta evangélica.

Pastores. Hay dos en Vigo, de los que uno es español y el otro (f. 55) inglés. No los hay en otros centros. A Trasmañó, va uno de aquéllos de Vigo.

Capillas y cultos. Existen dos capillas en Vigo y allí se celebran cultos: el domingo por la mañana tiene lugar la «Cena del Señor» y la escuela dominical, por la tarde la predicación del Evangelio. El martes por la tarde se tiene oración y el jueves la predicación con un concurso muy relativo. Los empleados de la compañía telegráfica transatlántica, una o dos veces al año, celebran el culto en el domicilio de uno de ellos bajo la presidencia de un Obispo del Ferrol o de Algeciras. En Trasmañó, tienen una capilla y todos los domingos se acerca un pas-

45 Informe del obispo de Jaén, Manuel Basulto Jiménez. Jaén, 18 junio 1930, en ASV, Arch. Nunz. Madrid, busta 848, fasc. 1, n. 23, ff. 69-70.

Hispania Sacra, LXIII

127, enero-junio 2011, 305-371, ISSN: 0018-215-X 
tor de Vigo; en Morgadanes, no tienen capilla, pero las cuatro mujeres, de las que tres son ancianas, profesan el protestantismo, se reúnen en casa de una de ellas y alguna vez las visita el pastor de Vigo. En Sotomayor, no hay capilla, alguna vez se acerca un pastor de Marín; en Camposancos, no hay capilla.

Escuelas. En Vigo, hay una escuela con una vieja maestra. Recientemente han abierto otra frecuentada por veinticinco o treinta niños de ambos sexos que son atraídos con regalos. En los otros pueblos no tienen escuela.

Asociaciones y fundaciones. No consta que tengan. $(f .56)$

Propaganda. En Vigo, se usan como medios de propaganda libros, folletos y una revista titulada «La aurora de Galicia». En Trasmañó, se adoptan los mismos medios y alguna vez proyecciones y pequeños regalos a los niños; en Morgadanes y Camposancos, no se hace propaganda; en Sotomayor, también se hace propaganda desde hace muchos años, pero ahora los hijos de los adeptos van con los otros niños a las escuelas nacionales, donde los maestros enseñan la doctrina católica sin que los padres protesten. Alguna vez se reparten libritos y folletos de la secta a la que pertenecen.

Conducta de las Autoridades. En Vigo y en Trasmañó, las autoridades se muestran pasivas y no dan importancia a los protestantes; en Mogardanes, los toleran, y en Sotomayor, no usan con ellos un trato diverso de aquél que usan con los otros ciudadanos.

$\underline{\text { Resumen. }}$ Protestantes, 183, cuatro familias, la mayor parte españoles. Capillas, tres; escuelas, dos. Se publica una revista. El número de los adeptos decrece en cada parroquia rural y tiende a aumentar en Vigo a causa de la inmigración extranjera. Sucede con frecuencia que los adeptos españoles protestantes se convierten al contraer matrimonio y alguna vez esto sucede también en las familias extranjeras. $(f$. 57) Dado que la escuela gratuita es el medio principal que se emplea para la propaganda protestante, el mejor medio para contrarrestarla sería fundar escuelas católicas en localidades adaptadas. ${ }^{46}$

\section{Archidiócesis de Toledo.}

Protestantes. En esta archidiócesis desde hace aproximadamente setenta años hay 500 en Camuñas por obra de un sacerdote apóstata; en Guadalajara, algunos obreros alemanes, no se conoce el número; en Chilluevar, desde hace 25 años hay de 400 a 500 del mismo país.

Pastores. No hay ni en Camuñas, ni en Chilluevar, pero se acercan de Madrid con frecuencia; en este último pueblo hay un luterano, no se conoce la secta de aquél que va a Camuñas.

46 Informe del vicario capitular de Tuy, Lorenzo Miguélez. Tuy, 24 abril 1930, en ASV, Arch. Nunz. Madrid, busta 848, fasc. 1, n. 54, ff. 170-171. 
Capillas. En Camuñas, no hay capilla y los cultos se celebran en la escuela con sermón del pastor que se acerca desde Madrid. Cada año preparan el árbol de Navidad. En Guadalajara, no hay capilla y no se celebran cultos; en Chilluevar, hay una capilla en la que se celebran cultos dos veces a la semana, cantando y explicando la Biblia, allí asisten los prosélitos del lugar. (f. 58).

Escuelas. En Camuñas, hay una con maestro. La frecuentan 24 alumnos y alumnas, hijos de los protestantes. En Guadalajara y Chilluevar no hay escuelas.

Asociaciones y fundaciones. No se da noticia.

Propaganda. En Camuñas, no se nota ninguna propaganda ni en Guadalajara. En Chilluevar, la hacen en la capilla y en conversaciones particulares.

Conducta de las Autoridades. En Camuñas, depende de aquéllos que constituyen el municipio que en este momento son favorables a los protestantes. En Guadalajara, no consta; en Chilluevar, se muestran indiferentes.

Los Arzobispos han tenido un cuidado especial en el envío de párrocos celosos a Camuñas, los cuales con la predicación han ido contrarrestando la predicación protestante y con esto quitan a ellos muchos adeptos, de tal modo que se puede decir que aquéllos que son protestantes lo son ahora por tradición de familia. El cardenal Arzobispo se preocupa también por la situación de Chilluevar, y allí ha enviado a su Auxiliar para que se informe personalmente del estado de las cosas, para asumir los medios oportunos para acabar con el protestantismo.

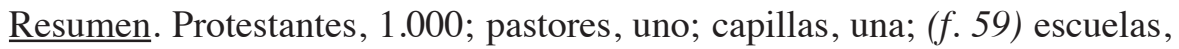
una, con 24 alumnos de los dos sexos. Propaganda, sólo en Chilluevar, durante los cultos y conversaciones privadas. Las autoridades se muestran favorables en Camuñas, indiferentes en Chilluevar. Nada consta en Guadalajara. ${ }^{47}$

\section{Archidiócesis de Granada.}

Protestantes. Hay desde hace ochenta años 20 familias en la misma ciudad, la mayor parte extranjeras: alemanas, suizas, protestantes de origen. En Escoznar, 24, gente sin alguna fe, sin convicciones, de la que se ignora su nacionalidad, habiéndose sumado cuando el gobierno español regaló al Duque de Wellington el llamado Soto de Roma por la ayuda que prestó a España en la Guerra de la Independencia, dando ocasión a la venida de los colonizadores ingleses. En Asquerosa, 40 españoles que tienen el mismo origen que los anteriores. Hay otros diseminados y sin organización.

Pastores. Hay uno en Granada, sacerdote apóstata; uno en Asquerosa, como el precedente, sacerdote apóstata.

${ }^{47}$ Informe del arzobispo de Toledo, Pedro Segura Sáenz. Toledo, 1 mayo 1930, en ASV, Arch. Nunz. Madrid, busta 848, fasc. 1, n. 51, ff. 151-155.

Hispania Sacra, LXIII

127, enero-junio 2011, 305-371, ISSN: 0018-215-X 
Capillas. En Granada, hay una capilla-escuela, cada domingo van allí los adultos, menos de treinta, leen la Biblia y cantan acompañados de armonio. El pastor más que el protestantismo les predica el comunismo y otras doctrinas disolventes. Tiene mujer e hijos. En Escoznar, no hay capilla y $(f .60)$ por tanto no celebran culto, más allá de la predicación que la tienen en el salón-escuela cuando se acerca el pastor. A estos actos son invitados los alumnos y sus padres. Generalmente les atiende el pastor de Granada, acompañado de aquél de Asquerosa. En Asquerosa, hay una capilla donde celebran cultos, sobre los que se guarda secreto. Según se dice, cantan salmos y el pastor recita sermones a los que asisten las familias pertenecientes a la secta. Pero es curioso notar que muchas de ellas se avergüenzan cuando se les llama «protestantes».

Escuelas. En la ciudad de Granada hay una escuela que es también capilla, dirigida por el mismo pastor. La casa es de la propiedad de los protestantes. La frecuentan alrededor de 30 niños, hijos de familias irreligiosas. En Escoznar, hay otra escuela que data también de la donación hecha a Sir Wellington, el cual por poblar su territorio con colonos ingleses fundó escuelas propias según sus creencias religiosas, escuelas que todavía hoy existen. Dichos pastores visitan alguna vez estas escuelas, haciendo regalos de vestidos y libros útiles a los alumnos, y de tabaco a sus padres. Años atrás venían a esta escuela unos sesenta niños, pero ahora este número va disminuyendo, $(f .61)$ gracias a la escuela que fundaron en aquel pueblo las Damas Apostólicas, ya que a la escuela protestante asisten ahora de 15 a 20 niños, mientras que a la de las Damas Apostólicas más de cincuenta. En Asquerosa, hay una escuela para niños y una nocturna para los adultos. Van 15 niños y 25 adultos. Los medios que se emplean para atraer a niños y jóvenes consisten en una biblioteca y máquinas de escribir, haciendo ver a los alumnos que aprenden a usarla que han de disponer de buenos puestos. Han prometido también un aparato de radio. El hecho de que el maestro nacional sea bastante viejo y casi inhábil contribuye a que aumente el número de los alumnos.

Asociaciones y fundaciones. No existen.

Conducta de las Autoridades. En Granada, no sólo usan una extrema tolerancia, sino una irritante benevolencia. En Escoznar y Asquerosa, tratándose de fracciones de común, no se ve clara la acción municipal.

Resumen. Protestantes, 64 y 20 familias, la mayor parte extranjeras: ingleses, alemanes y suizas. Pastores, dos, sacerdotes apóstatas. Capillas, una escuela-capilla y una capilla. Escuelas: tres con 65 alumnos. Propaganda: en Granada, no se sabe; en Asquerosa, biblioteca, regalos, máquinas de escribir, etc. $(f .62)$ No se conocen los medios que usan en otros lugares. ${ }^{48}$

48 Informe del arzobispo de Granada, Vicente Casanova y Marzol. Granada, 12 abril 1930, en ASV, Arch. Nunz. Madrid, busta 848, fasc. 1, n. 18, ff. 60-62. 


\section{Diócesis de Jaca.}

Protestantes. Hay en Jaca un maestro unido a una señora, la hermana de ésta con los hijos, doce en total. Proceden de Barcelona y residen aquí desde hace doce años. El hombre y la mujer son de origen protestante, y la señora parece extranjera. No se sabe exactamente a qué secta pertenecen, pero parecen luteranos. Hay también dos familias que se sospecha que sean protestantes, si bien no lo dicen abiertamente, haciendo bautizar a sus hijos en la Iglesia Católica.

Pastores. Hay un maestro que es de creer que celebra el culto en la escuela, porque el domingo se oye cantar a los niños. Cuando hay algún culto, aquéllos que asisten no son de Jaca sino que vienen de fuera, de la parte meridional de Francia, y esto sucede pocas veces. No hay ninguna otra capilla.

Escuelas. Hay una que funciona desde hace dieciséis años, y es frecuentada por unos cuarenta alumnos de los que un buen número son de la familia o hijos del maestro. La escuela ha sido cerrada por orden de la Dirección General de la Pública Instrucción, tras provocación del Señor Obispo. El maestro ha interpuesto $(f$. 63) recurso contra esta disposición, y el Ministro actual, señor Tormo, le ha dado la razón. Esta escuela se la combatió antes quitándole alumnos; pero el procedimiento era muy lento e ineficaz, porque a aquéllos que dejaban la escuela les sustituían otros, bajo el pretexto de que aquel maestro enseña mejor que los otros y no se inmiscuye en asuntos de religión. Los medios para atraer a los niños son el dinero y la enseñanza gratuita, pero sobre todo la pericia del maestro que sirve a los padres de pretexto, a pesar de que en Jaca hay más instituciones educativas que en otros pueblos: comunidades religiosas, escuelas nacionales y algún colegio particular.

Propaganda. Es muy limitada. El maestro no necesita hacerla porque las mismas familias que mandan sus hijos a la escuela, si bien, malas, no quieren ser protestantes, y mandan sus hijos al catecismo.

Asociaciones y fundaciones. No existen.

Conducta de las Autoridades. Es meramente pasiva, prescinden de los protestantes, pero no los atacan, porque se guardan mucho de que vayan extranjeros a habitar aquella región.

La Universidad de Zaragoza ha establecido en Jaca una universidad estival para los extranjeros, siendo admitidos todos $(f .64)$ sin distinción de religión ni sexo. No se habla de religión, pero el contacto continuo en la escuela y en los deportes es un grave peligro de propaganda protestante. Se ha llamado sobre esto la atención de la Dirección General, pero ésta ha respondido que tal es la condición de todas las Universidades. Esto mismo también resulta peligroso para la juventud del lugar. 
En Santa Cruz de la Serós, de 300 habitantes, hay un secretario del municipio que se dice que es protestante. Ha difundido folletos sectarios procedentes de Madrid, habiendo estado alguna vez en comunicación con el Pastor de la escuela arriba dicha. Asimismo ha intentado casar un hijo suyo por rito protestante.

Resumen. Hay doce y dos familias sospechosas. Pastores, uno; capillas, no hay; escuelas, una con cuarenta alumnos; asociaciones y fundaciones, ninguna; propaganda, muy limitada; autoridades, pasivas. Universidad estival fundada en Jaca para extranjeros, que puede ofrecer serios peligros para la fe de los católicos locales y especialmente para aquéllos que la frecuentan. ${ }^{49}$

\section{Archidiócesis de Zaragoza.}

Protestantes. Hay en Zaragoza nueve familias: una extranjera, $(f .65)$ y españolas las restantes; más unas sesenta personas, todas españolas. Existen desde hace sesenta años, y el núcleo principal está en la parroquia de San Pablo: parte pertenecen a los evangélicos, los otros no se sabe a qué secta pertenecen. En Ainzon, hay desde hace doce años dos protestantes españoles; en Cortes de Navarra, desde hace dieciséis años, un alemán empleado en la fábrica de azúcar; en Plasencia de Jalón, desde hace tres años, una familia de Sabiñán, compuesta de ocho personas; en Tauste, desde hace treinta y cinco años, una familia compuesta de tres hermanos españoles, hijos de protestantes; en Villanueva del Gallego, desde hace treinta o cuarenta años, diez españoles, todos apóstatas, pertenecientes parece ser a los evangélicos: no comen carne de cerdo, ni toman sangre de animales degollados ni bebidas alcohólicas. Se sirven del médico sólo para certificar los muertos, y observan escrupulosamente el domingo; en Utebo, desde hace cuarenta años, hay sesenta protestantes españoles.

Pastores. Hay uno solo en Zaragoza.

Capillas. Sólo hay una en la parroquia de San Pablo en Zaragoza, en la que se celebran los cultos el jueves, el sábado y el domingo, donde asisten una treintena de personas entre niños y adultos. En los otros pueblos no hay pastor ni capilla ni culto. Algunos protestantes de Villanueva del Gallego asisten a los cultos que se celebran en la capilla de Zaragoza. (f. 66)

Escuelas. En Zaragoza hay dos: una para niños y otra para niñas. La frecuentan sesenta o setenta alumnos que pagan tres o cuatro pesetas al mes. Tienen fama de enseñar mejor que en las otras escuelas. En Tauste, hay una escuela para niños con veinticinco o treinta alumnos. En los otros pueblos no hay.

${ }^{49}$ Informe del obispo de Jaca, Juan Villar Sanz. Jaca, 27 marzo 1930, en ASV, Arch. Nunz. Madrid, busta 848 , fasc. 1 , n. 22 , ff. 67-68. 
Propaganda. No se nota entre ellos el espíritu de proselitismo y ordinariamente no hacen propaganda. Alguna vez se han distribuido Biblias y folletos protestantes en los pueblos, pero con ningún resultado, y ha sido bastante una advertencia en el Boletín de la Diócesis para que pronto esta propaganda cesara.

Conducta de las Autoridades. De ordinario se muestran indiferentes, y al igual que el pueblo, no dan importancia a los protestantes. Sólo en Utebo son excesivamente tolerantes.

Medios para contrarrestar la propaganda. Se les podría dar un golpe decisivo en Zaragoza comprando la casa donde están instalados, porque dicen que difícilmente encontrarían otra, y creando escuelas católicas. En Tauste, se podría obtener del Inspector de Primera Enseñanza que ordenase el cierre de la escuela protestante, no teniendo el local las condiciones higiénicas requeridas por $(f .67)$ la ley. En los otros pueblos no es necesario tomar medidas extraordinarias.

Resumen. Protestantes, 145 y ocho familias. Pastores, uno. Capillas, una con frecuencia de treinta prosélitos. Escuelas, dos con unos 112 alumnos de ambos sexos. No hay asociaciones ni fundaciones. La propaganda es casi inexistente..$^{50}$

\section{Diócesis de Oviedo.}

Protestantes. Se cuentan en Toral de los Guzmanes diecinueve, de ellos uno es el pastor inglés anglicano, y los otros son españoles, existiendo desde 1894; en Rebollada (Mieres), hay tres familias extranjeras al servicio de una fábrica desde 1924; en Gijón, desde hace ocho años, hay 300, de los que 75 son protestantes de origen; en la parroquia de Besullo (Cangas de Narcea), hay tres familias, desde hace muchos años.

Pastores. Hay uno en Toral, pero que desde hace tiempo no reside. Tres en Gijón, luteranos; no hay en Rebollada ni en Besullo, pero se suelen acercar algunos, tanto luteranos como ingleses.

Capillas. Una en Toral en la que celebran los cultos de la secta el domingo y en otras circunstancias con asistencia de los prosélitos. En Rebollada, no hay capilla, ni culto. En Gijón, hay una capilla a la que van el domingo (f. 68) unas cuarenta personas, contando los niños. Se duda que exista otra en Gijón. En Besullo, no hay capilla ni prosélitos.

Escuelas. En Toral, hay una autorizada por el Rectorado de la Universidad bajo cuya dirección está un obrero de escasa cultura, que es al mismo tiempo el director de los cultos. Allí van muchos niños de los que algunos no tienen la edad reglamentaria para ser admitidos a escuelas públicas, y otros han sido ex-

50 Informe del arzobispo de Zaragoza, Rigoberto Doménech y Valls. Zaragoza, 7 junio 1930, en ASV, Arch. Nunz. Madrid, busta 848, fasc. 1, n. 61, ff. 175-178.

Hispania Sacra, LXIII

127, enero-junio 2011, 305-371, ISSN: 0018-215-X 
pulsados de éstas, habiendo sido atraídos por los protestantes con regalos. En Rebolleda y Gijón no tienen escuelas.

Asociaciones y fundaciones. No existen.

Propaganda. En Rebollada, distribuyen impresos; en Gijón, dan libros, folletos, programas, distribuyéndolos tanto en mano como a domicilio. Los pastores predican en la capilla. En Rebollada, no hacen propaganda; en Besullo, distribuyen hojas volantes.

Conducta de las Autoridades. En Toral, las autoridades han puesto prohibiciones valiéndose también de la ley. En Rebollada, no han tomado ninguna medida contra ellos porque los encuentran serios y laboriosos, no obstaculizan la acción católica, ni ofenden los sentimientos religiosos, ni hacen propaganda. Una de las familias bautiza espontáneamente los hijos en la Iglesia Católica y se espera que no tarde en convertirse. Son respetuosos con los sacerdotes, (f. 69) les gusta contribuir en la parroquia, mandan sus hijas a un colegio de religiosas, donde han sido admitidas esperando su conversión. Éstas no ofrecen ningún peligro para las otras alumnas, llegando incluso a estudiar el catecismo católico. En Gijón, las autoridades contemplan la ley íntegramente; en Besullo, vigilan y hacen observar la ley.

Medios para contrarrestar la propaganda. Se emplean las misiones, que dan excelente resultado; la fundación de escuelas católicas en oposición a las protestantes; la enseñanza del catecismo y la distribución de premios a los niños.

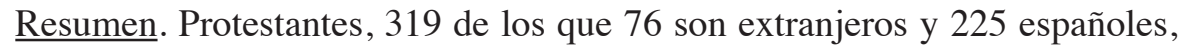
más tres familias extranjeras y tres españolas. Pastores, cuatro, de ellos tres luteranos, y se desconoce la secta del que falta. Capillas, dos, a una de ellas van aproximadamente cuarenta personas, no se sabe cuantos frecuentan la otra. Escuelas, una en Toral que no se sabe cuantos alumnos la frecuentan. Asociaciones y fundaciones no existen. Propaganda: distribuyen folletos, hojas y predican en la capilla. En Toral, las autoridades les ponen obstáculos aplicando con frecuencia las leyes; en Gijón, hacen observar la ley; en Rebollada, no hay (f. 70) necesidad de tomar medidas. Medios para contrarrestar la propaganda: misiones, escuelas católicas contra los protestantes, enseñanza del Catecismo y premios a los niños. ${ }^{51}$

\section{Diócesis Priorato de las Órdenes Militares.}

Protestantes. Desde hace un tiempo no preciso son doscientos en Valdepeñas, entre los que hay algún extranjero, pero la mayor parte son del país. En Puertollano, desde hace tiempo desconocido, cincuenta españoles; en Castellar

${ }^{51}$ Informe del obispo de Oviedo, Juan Bautista Luis Pérez. Oviedo, 2 mayo 1930, en ASV, Arch. Nunz. Madrid, busta 848, fasc. 1, n. 35, ff. 116, 118-119. 
de Santiago, cinco españoles que tienen las simpatías de las personas influyentes del pueblo por cuestiones políticas; en Santa Cruz de Mudela y en Argamasilla de Calatrava estuvieron, pero ahora se puede decir que no hay; en Tomelloso, dos o tres; en Manzanares, Infantes, Almodóvar del Campo, Cózar y Carrizosa desde hace tiempo cesó la propaganda y permanecieron pocos.

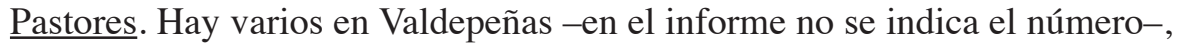
luteranos y baptistas, españoles y extranjeros; entre ellos un sacerdote apóstata de Cartagena que vive en concubinato, con hijos ya adultos, de conducta que es universalmente censurada.

Capillas. Se cuentan dos en Valdepeñas, una muy pequeña donde se celebran los cultos con poco concurso. En Puerto Llano, $(f$. 71$)$ celebran el culto el jueves y el domingo con discreto concurso de prosélitos, bajo la dirección de un pastor de Valdepeñas. En Castellar, intentan abrir de nuevo una capilla que ya tenían, e intentan celebrar reuniones.

Escuelas. En Valdepeñas, hay una para la instrucción elemental con pocos alumnos de las clases inferiores los cuales vienen atraídos por el dinero. En Puertollano, hay dos escuelas, una de niños y otra de niñas, con 115 alumnos los cuales pagan una cuota insignificante.

Asociaciones y fundaciones. En Valdepeñas, han fundado una asociación de mutuo socorro, en la que los socios cooperan con modestas sumas.

Propaganda. Los medios de propaganda son libros, folletos y estampas que distribuyen con generosidad, gratuitamente. En Valdepeñas, tienen un medio de particular eficacia, que es la asistencia a los enfermos pobres por parte de un médico inglés que, según se dice, ejercita sin tener el título académico. Sin embargo, el medio más eficaz que emplean en Valdepeñas y en Puertollano, es el dinero que los pastores distribuyen y que, según se dice, reciben de Inglaterra. En Castellar, practican la visita y la asistencia a los enfermos.

Conducta de las Autoridades. En Valdepeñas se muestran indiferentes; $(f .72)$ en Puertollano, francamente tolerantes; en Castellar, tienen amonestado al patrón de la casa en que se celebran las reuniones y han recurrido al Gobernador Civil; en Tomelloso, ha contribuido al fracaso de los protestantes y a tener que marchar la oposición franca y enérgica de un alcalde. En los otros pueblos las autoridades no oponen ninguna resistencia.

Resumen. Protestantes, 258, algún extranjero y el resto españoles. Pastores diversos, extranjeros y españoles, pero no se precisa el número. Capillas, tres. Celebran los cultos con poco concurso en Valdepeñas, y con mayor en Puertollano. Escuelas: una en Valdepeñas con pocos alumnos, y dos mixtas en Puertollano con 115 alumnos. Asociaciones: una de mutuo socorro en Valdepeñas. Propaganda: distribución de libros, folletos y estampas, con la asistencia médi- 
ca de uno que no tiene título académico, y con dinero y ayudas a los enfermos. Autoridades: alguna se muestran indiferentes, otras observan las leyes. ${ }^{52}$

\section{Diócesis de Lérida.}

Protestantes. En Lérida, hay treinta en la parroquia de San Juan, la mayor parte, mujeres y niños; en San Lorenzo Mártir, hay tres o cuatro familias de trabajadores; en San Andrés, un grupo de ignorantes y curiosos, la mayor parte ( $f$. 73) son mujeres extranjeras unidas en estos últimos años; en Alcarrás, 34 españoles de los que trece han sido rebautizados, no se sabe a qué secta pertenecen y existen desde hace veinticinco años; en Ballobar, tres o cuatro familias españolas, desde hace veinticinco años; en Laguarres, una familia del pueblo que emigró a Buenos Aires donde se pasó al protestantismo, haciendo desde 1910 dos o tres prosélitos; en Monzón, seis o siete familias evangélicas que frecuentan la casa del pastor; en Roselló, desde comienzos de siglo cuatro españoles bautizados en la Iglesia Católica, y esto a causa de la instalación de una fábrica cuyo propietario era inglés; en Serós, desde 1925, seis, de los cuales cinco son mujeres; en Velilla de Cinca, algún amigo del pastor que vive allí desde muchos años.

Pastores. Hay uno en Lérida con su secretario: el primero de Valencia y el otro de Lérida. Pertenecen a los «Adventistas del Séptimo Día». A Ballobar, fueron dos pastores evangélicos, uno con sede en Ballobar. En Monzón hay uno que parece evangélico.

Capillas. En Lérida, en la parroquia de San Juan, tienen un salón donde se reúnen una treintena de personas, la mayor parte mujeres y niños. Sus prácticas consisten en retener el sábado como día de fiesta, bautizar $(f$. 74) por inmersión, cantar himnos religiosos, leer o escuchar conferencias sobre argumentos bíblicos. En San Andrés de Lérida, se reúnen el domingo en el bajo de una casa, bajo la guía de un protestante, cantando himnos y salmos, y escuchan una predicación del director. En Alcarrás, poseen una pequeña casa donde cantan himnos, salmos y simulan la Santa Comunión. En Ballobar, tienen una capilla, donde se reúnen tres veces el domingo y una el jueves para leer y comentar la Biblia y celebrar bajo las dos especies la Comunión. Pertenecen a los evangélicos y admiten dos sacramentos: la cena y el bautismo de los adultos. En Languarres, tienen una conferencia anual. En Roselló, poseen una habitación muy pobre convertida en capilla, donde caben veinte personas. Allí se reúnen el jueves y el domingo para cantar y leer bajo la guía de un pastor que se acerca desde Barcelona por Navidad y San José. En Serós, se reúnen a cantar salmos en una sala llamada capilla.

Escuelas. En Monzón, el pastor tiene una escuela gratuita, a la que van seis o siete niños.

52 Informe del obispo-prior de Ciudad Real, Narciso de Estenaga y Echeverría. Ciudad Real, 23 abril 1930, en ASV, Arch. Nunz. Madrid, busta 848, fasc. 1, n. 12, ff. 46-48. 
Asociaciones y fundaciones. No existen.

Propaganda. En Lérida, se distribuyen folletos. (f. 75) En Ballobar, varía según las circunstancias: han tenido una escuela, publicado artículos, difundido folletos y Biblias, distribuido juegos para niños, abierto un cinematógrafo, tienen radiotelefonía, y con todo esto, después de veinticinco años, no han conseguido más prosélitos que las cuatro familias indicadas. Nada se dice en el informe de la propaganda en otros pueblos.

Conducta de las Autoridades. En Lérida, han intervenido. En Monzón, mantienen con el protestantismo una continua guerra, si bien no han podido conseguir que se cierre la escuela; en Roselló, se muestran hostiles. Los mismos hijos de los tres o cuatro protestantes del pueblo no siguen a los padres en sus ideas y prácticas religiosas. En los otros países las autoridades se muestran indiferentes. Los párrocos son del parecer que, dado el escaso número de protestantes, no se haga caso de ellos, sería darles importancia. No por esto los párrocos dejan de trabajar todo lo posible para acabar con estos focos de protestantismo.

Resumen. Protestantes, 78, y dieciséis familias, y algún que otro desaparecido, todos españoles. Pastores, tres, un adventista y dos de la secta evangélica. Capillas, dos. (f. 76) Escuelas, una con seis o siete alumnos. Propaganda: se hace con la distribución de folletos, hojas, Biblias, juegos para los niños, cinematografía y radiotelefonía. Autoridades: en Lérida, indiferentes; en otras partes, hostiles. ${ }^{53}$

\section{Diócesis de Santander.}

Protestantes. Hay un núcleo en la ciudad compuesto de catorce hombres y treinta mujeres, todos españoles, si bien a los cultos asiste un número mayor de personas. No se sabe desde cuándo existen.

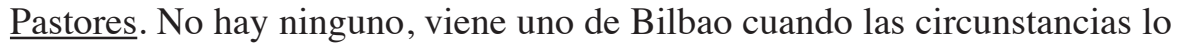
requieren.

Capillas. No se dice si existe alguna. Los cultos tienen lugar el jueves y el sábado de cada semana, mañana y tarde. No se sabe en qué consisten.

Escuelas. Hay una escuela con 150 alumnos, de los que quizás una parte se acerca por no hallar otro centro donde instruirse. Hay dos maestros que reciben el estipendio del «Comité del Esfuerzo Cristiano». Se cree que los alumnos no son recibidos del todo gratuitamente.

Asociaciones y fundaciones. No existen. ${ }^{54}$ (f. 77).

53 Informe del vicario general de Lérida, Rafael García. Lérida, 10 junio 1930, en ASV, Arch. Nunz. Madrid, busta 848, fasc. 1, n. 25, ff. 73-74.

${ }_{54}$ Informe del obispo de Santander, José Eguino y Trecu. Santander, 28 mayo 1930, en ASV, Arch. Nunz. Madrid, busta 848, fasc. 1, n. 40, f. 125.

Hispania Sacra, LXIII

127, enero-junio 2011, 305-371, ISSN: 0018-215-X 


\section{Diócesis de Ávila.}

Protestantes. Hay siete españoles en Arenas de San Pedro desde abril del presente año; algunos pocos españoles en Sotillo de la Adrada, no se sabe desde cuando; diecinueve evangélicos, españoles, en Piedralaves, entre ellos cinco, sin ser bautizados, y siete españoles, rebautizados, desde hace dos años. En Guisando, hay seis o siete personas que se dicen protestantes, españoles, apóstatas, pertenecen a los rebautizantes.

Pastores. Hay cuatro, de los cuales dos son ingleses y los otros dos españoles. Tres son evangélicos, y del cuarto no consta a qué secta pertenezca. Aquél de Sotillo de la Adrada es un desgraciado. A Guisando va un pastor inglés.

Capillas. Se cuentan dos. En Arenas de San Pedro, celebran el culto con oraciones, cánticos, discursos, pero con poco concurso. No consta lo que se hace en los otros pueblos.

Escuelas. No tienen. Intentaron crear una en Sotillo, pero a instancia del párroco, el alcalde lo impidió.

Asociaciones y fundaciones. No existen.

Propaganda. Usan discursos y distribución de Biblias, folletos, hojas y limosnas.

Conducta de las Autoridades. Hecha excepción de aquélla de Sotillo de la Adrada, se muestran pasivos e indiferentes. 55

Diócesis de Astorga.

Protestantes. Desde 1890, cuarenta en San Clodio del Sil, de la provincia de Lugo, españoles; $(f .78)$ desde 1912, seis españoles en Castrogonzalo; en Torre del Valle, ocho españoles que por enemistad con el párroco llamaron a los protestantes; en Barcial del Barco, no hay prosélitos, pero el pastor va dos veces a la semana.

Pastores. Hay dos, uno español y el otro inglés. Sin embargo, a San Clodio van pastores de Lugo y de Vigo.

Capillas. Se cuentan una en Castrogonzalo en la que se celebran cultos que consisten en leer y comentar la Biblia. En invierno se hacen representaciones cinematográficas a las que el público especialmente la juventud asiste porque la entrada es gratuita. En San Clodio celebran el culto en una habitación leyendo y comentando la Biblia. Después de esta lectura se hacen representaciones cinematográficas y se distribuyen dulces y juegos a los niños y folletos. Como el pastor se dice médico, van a consultarlo algunos enfermos a los que da gratuita-

55 Informe del obispo de Ávila, Enrique Pla y Deniel. Ávila, 16 junio 1930, en ASV, Arch. Nunz. Madrid, busta 848, fasc. 1, n. 3, ff. 12-15. 
mente medicinas y como recompensa pide que asistan a los cultos. A Torre del Valle va también el pastor de Castrogonzalo. Celebra el culto cada domingo en una casa particular donde al principio iba mucha gente por curiosidad, pero ahora se ha reducido a algunos enemigos del párroco. Los otros del pueblo ven con desprecio la acción protestante. $(f .79)$

Escuelas. Quisieron crear una años atrás, pero las autoridades no se lo permitieron.

Asociaciones y fundaciones. No existen.

Conducta de las Autoridades. Se muestran pasivas en San Clodio y en Barcial de Barco. ${ }^{56}$

\section{Diócesis de Badajoz.}

Protestantes. Desde hace pocos años en la ciudad de Badajoz hay un pastor con su señora, cuatro hijos, y algún otro.

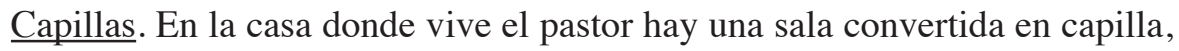
donde dos veces a la semana se dan algunas enseñanzas precedidas y seguidas de oraciones, y concluidas con cánticos.

Escuelas. En la misma capilla se hace escuela, pero se acercan sólo, más allá de los cuatro hijos del pastor, otros dos niños, y de quince a dieciocho adultos que van más bien por curiosidad.

Asociaciones y fundaciones. No existen.

Propaganda. Se hace distribuyendo folletos, hojas y Biblias protestantes, y promoviendo excursiones a los pueblos vecinos durante las cuales se difunden impresos.

Conducta de las Autoridades. No hacen caso del pastor, así también hacen todos los demás y por esto no hacen prosélitos..$^{57}(f .80)$.

\section{Diócesis de Córdoba.}

Protestantes. Hay en Córdoba desde el año 1870, pero no se conoce el número exacto. Son españoles y se dicen evangélicos.

Pastores. No consta que existan, pero es de suponer que sí.

Escuelas. Tienen escuela en la misma capilla para niños de ambos sexos, desde los cinco a los diez años. La frecuentan alrededor de cincuenta alumnos,

\footnotetext{
56 Informe del obispo de Astorga, Antonio Senso Lázaro. Astorga, 9 junio 1930, en ASV, Arch. Nunz. Madrid, busta 848, fasc. 1, n. 2, ff. 8-9.

57 Informe del obispo de León y administrador apostólico de Badajoz, Ramón Guillamet y Coma. Badajoz, 3 mayo 1930, en ASV, Arch. Nunz. Madrid, busta 848, fasc. 1, n. 4, f. 17.

Hispania Sacra, LXIII

127, enero-junio 2011, 305-371, ISSN: 0018-215-X
} 
número que tiende a disminuir. Los llevan los padres porque para admitirlos no exigen documentos. Según el Inspector de Enseñanza Elemental, funciona ilegalmente, pero los Gobernadores no se atreven a cerrarla.

Asociaciones y fundaciones. No existen. Poseen una casa que está inscrita a nombre de Duncan Cherry William Vallace: están subvencionados desde Inglaterra, por medio de un jefe que reside en Madrid.

Propaganda. La hacen repartiendo Biblias.

Conducta de las Autoridades. No consta.

En el ámbito popular no han tenido buena acogida. En alguna población de la diócesis trabajan intensamente, pero sus resultados desaparecen enseguida con la misión. Ha habido invasiones transitorias en otras partes, pero han desaparecido y sólo subsisten algunos restos en la minería del Pueblo Nuevo, que son gestionados por una compañía francesa, pero no tienen pastores, $(f .81)$ no hacen propaganda y mandan sus hijos a los colegios católicos. De vez en cuando aparecen en los pueblos, especialmente en tiempo de ferias, con la venta de Biblias de las que sin embargo venden muy pocas, y éstas pocas son retiradas fácilmente. ${ }^{58}$

\section{Diócesis de Mallorca.}

Protestantes. Hay algunos en la ciudad de Palma, calle de los Olmos, pero no se dice el número ni el tiempo en que surgieron, ni la nacionalidad. En Capdepera, pueblo en el que debido a su proximidad a Menorca supuso la entrada del anglicanismo, hay muchas familias que se han convertido al catolicismo, de tal modo que aquéllas que profesan el protestantismo son muy pocas. En Mallorca se siente horror por todo aquello que haya de protestantismo. Los vendedores de Biblias son despreciados en todas partes y perseguidos por los mismos fieles. De Mallorca no se dan otras informaciones y por eso no se sabe si hay pastores, capillas, escuelas, asociaciones, fundaciones, y si se celebran cultos. Se añade sólo que, según informaciones, los turistas ingleses que visitan frecuentemente la isla se reúnen en una casa particular para celebrar los cultos y las ceremonias del rito protestante. ${ }^{59}(f .82)$.

\section{Diócesis de Lugo.}

Protestantes. Hay una decena de españoles en la parroquia de San Froilán, en los alrededores de Lugo, que se hicieron protestantes por los sermones de

\footnotetext{
58 Informe del obispo de Córdoba, Adolfo Pérez y Muñoz. Córdoba, Fiesta de Pentecostés 1930, en ASV, Arch. Nunz. Madrid, busta 848, fasc. 1, n. 14, ff. 51-52.

59 Informe del vicario capitular de Mallorca, Jaime. Mallorca, 4 mayo 1930, en ASV, Arch. Nunz. Madrid, busta 848, fasc. 1, n. 29, ff. 88-91.
} 
uno del lugar que consiguió reunir un centenar de prosélitos en 1921 o 1922, reducidos ahora, como se ha dicho a una decena. En Villar, fracción de Taboada, hay de 40 a 45 españoles que se hicieron protestantes en 1870 por diferencias con el párroco.

Pastores. En San Froilán hace de pastor uno del pueblo que fue a trabajar al Ferrol, donde se hizo protestante. Cuando regresó a San Froilán constituyó el foco del protestantismo y ejerce de pastor. En Villar, hay un pastor español ya viejo, que no se sabe de donde haya venido y a qué secta pertenezca.

Capillas. Hay una evangélica en Villar. Los cultos que allí se celebran, se reducen a la lectura de la Biblia y a los sermones del pastor. En San Froilán se reúnen en la sala de una casa particular que llaman «Cámara Evangélica», leen la Biblia y alguna vez hacen prácticas espiritistas.

Escuelas. En Villar había una, pero se cierra a instancia del Obispo.

Asociaciones y fundaciones. No existen. (f. 83).

Conducta de las Autoridades. No las favorecen.

Se espera que en breve desaparezcan estos focos, porque los adeptos disminuyen rápidamente. Ningún católico se hace protestante y por el contrario los protestantes se convierten a la hora de la muerte y cuando contraen matrimonio con algún católico. Además la mitad de las familias protestantes permiten que sus hijos sean bautizados y educados en la Iglesia Católica, que asistan al catecismo, escuchen la Misa y reciban los Sacramentos. ${ }^{60}$

\section{Diócesis de León.}

Protestantes. Hay siete en León desde hace treinta años. No hay pastor ni capilla. En la ciudad de León se abrió el 24 de julio de 1921, una capilla evangélica, en la parroquia de San Martín. Las protestas y la acción del obispo supuso su cierre. Se reúnen el domingo, por la mañana y por la tarde, y asisten a estas reuniones, además de los dichos, otros tres padres y una hija. No tienen escuela. Hacen propaganda vendiendo Biblias, libros del Antiguo Testamento, Evangelios y otros libros de la secta, pero los efectos son nulos.

Pastores. Vienen de otras diócesis y alguna vez van a los pueblos de León a difundir o vender Biblias, folletos, etc.

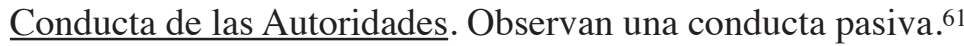

\footnotetext{
60 Informe del obispo de Lugo, Rafael Balanza y Navarro. Lugo, 29 marzo 1930, en ASV, Arch. Nunz. Madrid, busta 848, fasc. 1, n. 26, ff. 75-76.

${ }^{61}$ Informe del obispo de León, José Álvarez Miranda. León, 19 abril 1930, en ASV, Arch. Nunz. Madrid, busta 848, fasc. 1, n. 24, f. 71.

Hispania Sacra, LXIII

127, enero-junio 2011, 305-371, ISSN: 0018-215-X
} 


\section{Diócesis de Málaga.}

Protestantes. En Málaga pertenecen a la Colonia inglesa, y (f. 84) allí hay algún español: no se sabe cuántos son, ni desde cuándo han venido. En Cortes de la Frontera hay una familia compuesta por los padres y por tres o cuatro hijos pequeños. En total, siete u ocho personas, probablemente de origen inglés. No se sabe cuanto tiempo hace que han venido.

Pastores. Hay en Málaga uno, español.

Capillas. Una en el cementerio protestante donde la colonia inglesa celebra sus cultos, que no se dice en qué consisten, a la mañana para los niños, a la tarde para los adultos. Hay también otro centro donde se celebran los cultos a las diez de la mañana y a las nueve de la noche del domingo. No se sabe qué concurso exista, ni en qué consisten los cultos.

Escuelas. Hay dos escuelas. De una de ellas es director el pastor con dos profesores y dos profesoras, todos españoles. La frecuentan cincuenta niños y cien niñas. Parece que dependa de una sociedad bíblica holandesa. A la otra escuela van jóvenes, alcanzando mayores daños porque allí se celebran matrimonios. Se dice que depende de un centro alemán.

Asociaciones y fundaciones. No se sabe nada sobre este punto, y tampoco se dice nada de los medios de propaganda ni de la conducta de las autoridades. En Málaga, los protestantes tienen un cementerio propio. En $(f .85)$ Cortes de la Frontera, no se sabe si hay pastor, capilla o escuela. En la relación se añade que en la localidad rural llamada «Los Rubios» hay un centro protestante que hace mucho daño porque desarrolla su propaganda entre gente sencilla y pobre. Y no se añade nada más. ${ }^{62}$

\section{Diócesis de Orense.}

Protestantes. Hay solo en la parroquia de Nigueiroá. Pertenecen a cuatro familias, pero más allá de éstas que han manifestado abiertamente ser protestantes, hay otras personas que están incondicionalmente a las órdenes del pastor, si bien no asisten al culto. Son todos españoles, y datan de 1921, aproximadamente. En la localidad no hay pastor y va a dirigir los cultos aquél que reside en Bargeles u otros en determinadas épocas. Se trata de súbditos ingleses evangélicos.

Capillas. Han alquilado un local en el que celebran el culto dos veces a la semana. No tienen escuela, pero uno de Nigueiroá, sin carácter oficial, tiene una especie de escuela a la que van seis niños, hijos de los protestantes.

62 Informe del obispo de Málaga, Manuel González García. Málaga, 9 junio 1930, en ASV, Arch. Nunz. Madrid, busta 848 , fasc. 1 , n. 28 , f. 85 . 
Asociaciones y fundaciones. No existen. $(f .86)$.

Propaganda. Los medios que emplean son varios según las circunstancias. Los principales: la distribución de folletos y libros en las ferias, crítica de los aranceles parroquiales, oferta de enseñar inglés a los que quieren emigrar a Estados Unidos, etc.

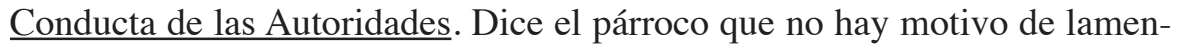
to, porque fuera de cualquier acto poco sensato, se han mostrado siempre próximos a los sacerdotes católicos. Digno de especial elogio y del más sincero aplauso es el señor juez del distrito, Don Luis Rubido, el cual no sólo ha demostrado su rectitud en su carga, sino también como particular está desplegando una gran actividad y celo a favor de los intereses católicos. ${ }^{63}$

\section{Diócesis de Plasencia.}

Protestantes. Hay desde principios de siglo de quince a treinta en Ibahernando, todos españoles.

Pastores. Hay uno en Ibahernando, italiano, luterano, y otro español en Santa Amalia, que no se sabe a qué secta pertenezca. Aquél de Ibahernando fue condenado a la cárcel por el tribunal de Cáceres tras denuncia del párroco por vilipendio del culto católico.

Capillas. Hay una en Ibahernando, nominal porque allí no se (f. 87) celebran cultos. No consta que haya en Santa Amalia ni que se celebren cultos.

Escuelas. En Ibahernando hay una, que cesó por falta de alumnos. En Santa Amalia no hay.

Asociaciones y fundaciones. No existen.

Propaganda. En Ibahernando emplean la «Hoja Evangélica». Nada se sabe de Santa Amalia.

Conducta de las Autoridades. Aquéllas del Directorio favorecen a los protestantes de Ibahernando. Las actuales no se sabe, en Santa Amalia son favorables. El Obispo considera que no es necesario tomar medidas porque se nota que van en disminución. ${ }^{64}$

\section{Diócesis de Salamanca.}

Protestantes. Hay un grupo de españoles desde tiempo remoto en Salamanca, en el barrio llamado «de la Prosperidad», sin precisar su número.

${ }^{63}$ Informe del obispo de Orense, Florencio Cerviño González. Orense, 29 marzo 1930, en ASV, Arch. Nunz. Madrid, busta 848, fasc. 1, n. 32, ff. 98-100.

${ }^{64}$ Informe del obispo de Plasencia, Justo Rivas Fernández. Plasencia, 3 abril 1930, en ASV, Arch. Nunz. Madrid, busta 848, fasc. 1, n. 38, f. 123. 
Pastores. No hay pastor. Existía un individuo español, que llamaban párroco. Tienen una capilla, pero el concurso no excede aquél de tres docenas de mujeres que van porque se les paga. No se sabe en qué consisten los cultos ni cuándo los celebran.

Escuelas. Hay una que tiene cuarenta alumnos entre niños y niñas.

Propaganda. Los medios de propaganda son las limosnas a los pobres, las conferencias y alguna vez la distribución de Biblias. $(f .88)$.

Meses antes abjuraron ante el Vicario General dicho párroco, su señora y su ayudante; y antes habían abjurado también otras personas que frecuentaban la capilla. Pero los otros comenzaron entonces a moverse más de lo normal, y en dos o tres casas de pobres dieron explicación del Evangelio; pero por intervención de la Acción Católica de la Mujer, se consiguió hacerles cesar.

En la diócesis, fuera de la Sede, no existen ni capillas ni escuelas. En Tejares, próximo a Salamanca, se reunían algunos asalariados y simpatizantes, aproximadamente una veintena, para escuchar las explicaciones del Evangelio, pero un año atrás abjuró la familia en cuya casa se celebraban las reuniones y el foco se extinguió. Fuera de esto sólo con ocasión de las ferias aparece algún repartidor de Biblias, que procura retirarse enseguida.

Medios para contrarrestar la propaganda. En este año se dieron en Salamanca cuatro misiones en diversos pueblos, denunciando los errores de la secta con óptimo resultado. Además se ha ampliado la enseñanza del Catecismo y la Acción Católica docente. Por el momento no hay que tomar ninguna medida especial. ${ }^{65}(f .89)$

\section{Diócesis de Tarragona.}

Protestantes. Hay unos 150 españoles en Reus desde hace cincuenta años. Se trata de gente vulgar que busca protección. En Pont de Armentera hay ocho: el resto de una especie de secta protestante que existía en aquel pueblo. Datan desde el mismo tiempo de aquéllos de Reus y son sobre todo españoles. En La Riba son veinte: obreros venidos casi todos desde Alemania y desde Suiza para trabajar en una fábrica. No hay ninguno español. Se cuentan en Tarragona algunos extranjeros dedicados al comercio y a la industria, y otros que pasan allí algún tiempo, pero no hacen ostentación alguna de las propias ideas religiosas. Datan de hace cincuenta años o más.

Pastores. Hay uno en Reus de desconocida nacionalidad y confesionalidad. Durante un tiempo estuvo uno en Tarragona y se intentó que permaneciera, como en Pont de Armentera, pero el intento ha caído en el vacío.

65 Informe del obispo de Salamanca, Francisco Frutos Valiente. Salamanca, 31 marzo 1930, en ASV, Arch. Nunz. Madrid, busta 848, fasc. 1, n. 39, ff. 124. 
Capillas y culto. No se dice en el informe si existen y si celebran cultos. Sólo se hace una pequeña aproximación con relación a Reus, donde se dice que el pastor habla a los adeptos sin decir si pertenece a ésta o aquélla secta, pero combatiendo a la Iglesia Católica. (f. 90).

Escuelas. En Reus tienen una escuela gratuita a la que los niños van poco, porque próxima a ella se abrió una escuela católica también gratuita, dirigida por un sacerdote. No se sabe si hay escuelas en otros pueblos.

Asociaciones y fundaciones. No existen.

Propaganda. Ordinariamente es escasa y está disimulada. En Reus se sirven de conferencias en alguna casa particular anunciándolas con folletos, venden a precio reducido en las ferias y mercados Biblias y libros protestantes, envían por correo o distribuyen a mano los periódicos y panfletos protestantes.

Medios para contrarrestar la propaganda. Son apropiados a las circunstancias: muchas veces no se le da importancia, otras veces se aprovecha la oportunidad para exponer la doctrina católica en forma apologética combatiendo las doctrinas opuestas, en otros casos se reclama por medio de los periódicos la atención de los párrocos para que no se dejen sorprender en los casos de reparto de venta de libros, etc. Se adopta también la colaboración de los buenos católicos. ${ }^{66}$

\section{Diócesis de Tortosa.}

Protestantes. Hay cinco o seis familias españolas desde $(f .91)$ hace años. En Flix hay un pequeño foco de extranjeros que llegaron allí con ocasión de la fundación de una importante fábrica, donde también ellos habitan desde hace años.

Pastores. No hay pastores en la diócesis. A Ginestar, de vez en cuando, va uno que tiempo atrás vivía en este pueblo, del que es originario. Era entonces morador, haciendo al mismo tiempo de pastor. Más tarde se transfirió a Reus. Ni siquiera en Flix hay pastor a donde se acerca uno de Barcelona con ocasión de algún bautismo o la celebración de cualquier acto religioso.

Capillas. No hay. En Ginestar, cuando se acerca el pastor se reúnen las cinco familias, pero no se sabe si celebran reuniones puramente religiosas. En Flix no practican públicamente ningún rito.

Asociaciones y fundaciones. No existen.

Propaganda. No se conocen los medios de propaganda que utilizan.

Los protestantes de Flix no son hostiles al catolicismo, que por desgracia en aquel pueblo está en decadencia, y la fábrica contribuye financieramente a la

${ }^{66}$ Informe del arzobispo de Tarragona, Francisco Vidal y Barraquer. Tarragona, 14 junio 1930, en ASV, Arch. Nunz. Madrid, busta 848, fasc. 1, n. 48, ff. 145-147.

Hispania Sacra, LXIII

127, enero-junio 2011, 305-371, ISSN: 0018-215-X 
construcción de la capilla de la Comunión en la parroquia. Otros pueblos de la diócesis son objeto de incursiones de parte de los protestantes, pero con el único fin de vender Biblias. ${ }^{67}$ (f. 92).

\section{Diócesis de Segorbe.}

Protestantes. Hay uno en Alcublas que por su condición social e intelectual es objeto del público desprecio. Dos en Titaguas donde leen la Biblia, pero no hacen propaganda, y uno de ellos deja que su mujer cumpla las prácticas religiosas; dieciséis en Jerica, desde 1908, todos españoles. En Caudiel desde 1908 dos familias de las que una sin hijos y con tres la otra, son fruto quizás de un centro que hubo allí en Teruel; diecienueve en Sort de Ferrer que deben haber sido iniciados al protestantismo en Argentina, donde emigraron. Se dicen evangélicos espirituales.

Pastores. En Jerica suelen actuar como pastor dos de los adeptos y en Sort de Ferrer uno de ellos, si bien no son tales. En los otros pueblos no hay pastor.

Capillas y cultos. En Jerica se suelen reunir en la sala de una casa de alquiler todos los sábados, tocan el armonio y recitan salmos. El concurso es muy irregular. En Caudiel no hay casa donde reunirse y para poder hacerlo alguna vez se reúnen con los de Jerica del que siguen las inspiraciones. (f. 93) En Sort de Ferrer tuvieron una capilla, y ahora se reúnen sólo cuando regresa alguno de ellos desde Buenos Aires. En los otros pueblos no hay culto.

Escuelas. En Jérica tuvieron una, pero debieron cerrarla porque se presentó sólo una niña. En los otros pueblos no hay.

Asociaciones y fundaciones. No existen.

Propaganda. El medio que emplean en Jérica es la revista «El fin de los tiempos» que ahora no distribuyen más porque ven que, apenas distribuida, es conducida a las llamas. Se desconoce si se hace propaganda en Caudiel; no se hace en Sort de Ferrer.

Conducta de las Autoridades. Su conducta en Jérica es de tolerancia, sin permitir ninguna manifestación externa, de tal modo que cuando se intentó hacerla, los promotores fueron denunciados y castigados. Se desconoce la actitud de las autoridades en los otros pueblos. ${ }^{68}$

\section{Diócesis de Tarazona.}

Protestantes. Hay un ingeniero en Olvega, del que no se dice la nacionalidad ni el tiempo desde el que está. En Morata de Jalón hay dos familias, una com-

\footnotetext{
${ }^{67}$ Informe del obispo de Tortosa, Félix Bilbao Ugarriza. Tortosa, 27 abril 1930, en ASV, Arch. Nunz. Madrid, busta 848, fasc. 1, n. 52, f. 156.

${ }^{68}$ Informe del obispo de Segorbe, Fr. Luis Amigó y Ferrer, OFMCap. Segorbe, 22 mayo 1930, en ASV, Arch. Nunz. Madrid, busta 848, fasc. 1, n. 42, ff. 130-131.
} 
puesta de madre y de tres hijos, en total nueve personas. Pero uno de los hijos de la segunda de estas $(f$. 94) familias se bautizó y contrajo matrimonio en la Iglesia Católica.

Pastores, capillas, escuelas, asociaciones y fundaciones de ningún género. No hay.

Propaganda. En el pueblo de Tobed, arciprestazgo de Calatayud, han intentado cinco años atrás el hacer prosélitos entre las personas más instruidas del pueblo, pero sin ningún resultado. En los otros pueblos de la diócesis, la propaganda se ha restringido a la distribución de los libros y periódicos, con preferencia en los pueblos más importantes; pero sobre todo, a pesar de la indiferencia religiosa que se lamenta en varios lugares, los fieles han entregado a los respectivos párrocos los libros y los folletos recibidos para que fueran destruidos, o los han destruido ellos personalmente una vez que fueron advertidos por los párrocos. Ninguna otra noticia se da de la diócesis de Tarazona. ${ }^{69}$

\section{Archidiócesis de Valladolid.}

Protestantes. Hay siete familias en Valladolid, de ellas cinco son españolas y dos extranjeras, y además otros trece españoles. Su presencia data desde 1900.

Pastores. Hay un extranjero.

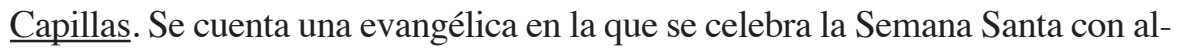
guna solemnidad, anunciándola por medio de $(f$. 95) folletos. Allí va poca gente.

Escuelas. Existen dos en un solo edificio, dirigidas por un maestro y dos maestras. Son frecuentadas por aproximadamente 140 niños que son mandados allí por los padres, no por motivos religiosos, sino para que reciban instrucción gastando poco, dada la falta de escuelas en el barrio y sobre todo porque en general los padres de los alumnos son socialistas y buscan que los hijos aprendan, sin preocuparse de la religión. Los niños referidos van luego al catecismo parroquial, y su número disminuye cuando aumentan las escuelas nacionales y las católicas privadas.

Asociaciones y fundaciones. No existen.

Propaganda. No se conocen los medios de propaganda que utilizan.

Conducta de las Autoridades. Están dispuestas a usar los medios legales.

En esta diócesis hubo protestantes en Tudela del Duero, pero desaparecieron, y así también en Cigales, sesenta años atrás. Abrieron una capilla y escuelas mixtas, con muchos alumnos, pero desde hace más de seis años se están

69 Informe del obispo de Tarazona y administrador apostólico de Tudela, Isidro Gomá y Tomás. Tarazona, 1 abril 1930, en ASV, Arch. Nunz. Madrid, busta 848, fasc. 1, n. 47, f. 141.

Hispania Sacra, LXIII

127, enero-junio 2011, 305-371, ISSN: 0018-215-X 
cerrando por falta de niños. A la capilla no va nadie porque han permanecido apenas cuatro personas adaptadas al protestantismo y éstas lo son por respeto humano, como lo prueba el hecho de que el mismo encargado de la capilla y de la casa del Pastor, que va allí alguna vez desde Valladolid, ha bautizado sus sobrinos en la Iglesia Católica y $(f .96)$ él mismo se ha propuesto bautizarse y contraer matrimonio en la Iglesia Católica. ${ }^{70}$

\section{Diócesis de Vich.}

Protestantes. En la colonia llamada «La Farga de Bebié» (San Quírico de Besora) desde hace nueve años hay tres familias suizas del Cantón de Zurich, no se sabe a qué secta pertenecen, y dicen que han sido bautizadas en el nombre del Padre, del Hijo y del Espíritu Santo. En la colonia «Fabra y Coats» (San Vicente de Torrelló) hay dos familias: la del director y la del ingeniero, compuestas en total por nueve personas. Son originarias de Escocia y residen en dicha colonia, una familia desde 1916 y la otra desde 1918, aquéllas que las precedieron desde 1896. No se sabe a qué secta pertenecen, pero parece que son baptistas. De hecho, son indiferentes, si bien alguna vez se reúnen en Barcelona.

En las colonias no hay pastores, ni cultos, ni escuelas, ni prosélitos, ni asociaciones, ni fundaciones, ni siquiera se hace propaganda. En la primera colonia viven en buena armonía con las autoridades, y los hijos van a las escuelas católicas que están en la colonia, a expensas del patrón protestante que reside en Barcelona. En la segunda, las autoridades mantienen con dichas familias ( f. 97) una relación puramente oficial: los hijos del ingeniero se educan en un Colegio de Barcelona. ${ }^{71}$

\section{Diócesis de Urgel.}

Protestantes. Hay desde hace treinta años en la parroquia de Térmens, son siete hombres y once mujeres.

Pastores. Hay dos encargados de la secta y residen en Térmens. Son pagados desde Inglaterra y dependen de un pastor inglés que reside en Barcelona y que visita frecuentemente los adeptos de Térmens.

Capilla. Hay una llamada evangélica. No se hace referencia a los cultos que se celebran.

Escuelas. No hay, pero una vez al año distribuyen vestidos a los niños que van a la capilla.

\footnotetext{
70 Informe del arzobispo de Valladolid, Remigio Gandánsegui y Gorrochátegui. Valladolid, 14 mayo 1930, en ASV, Arch. Nunz. Madrid, busta 848, fasc. 1, n. 57, ff. 162-163.

${ }^{71}$ Informe del obispo de Vich, Juan Perelló y Pou. Vich, 15 abril 1930, en ASV, Arch. Nunz. Madrid, busta 848, fasc. 1, n. 58, f. 164 .
} 
Conducta de las Autoridades. Se comportan pasivamente.

Medios para contrarrestar la propaganda. Se fundó en aquella parroquia, hace siete años, un colegio de Hermanas Agustinas de Ultramar que trabajan con gran fruto. ${ }^{72}$

\section{Diócesis de Zamora.}

Protestantes. Hay 36 en Villaescusa desde 1879, todos españoles de aquel pueblo y pertenecientes a la secta evangélica.

Pastores. Hay un subdiácono apóstata, nativo del lugar. (f. 98).

Capillas. Hay una y celebran cultos el jueves para conmemorar la Cena del Señor, y el domingo para la explicación del Evangelio y el canto de los Salmos.

Escuelas. No hay.

Asociaciones y fundaciones. No existen.

Medios para la propaganda. Hacen la distribución de Biblias, libros, folletos e impresos volantes.

Conducta de las Autoridades. No se preocupan de ellos. Algunos son tenaces por egoísmo, otros por fanatismo y otros por capricho. Durante los últimos años el número de los adeptos ha ido decreciendo y hace cuatro meses tuvieron el golpe más duro con la abjuración del pastor principal, del cual era auxiliar el actual. En la visita pastoral el Obispo ha podido constatar cuanto es sólida la fe de los diocesanos. Todos se han acercado a la Santa Comunión que tuvo lugar con ocasión de dicha visita, del más pequeño al más viejo. Se han impartido misiones con fruto y allí han asistido también algunos protestantes. Se han establecido la «Propagación de la Fe» y la «Santa Infancia», y es de esperar que el número de los protestantes vaya disminuyendo de día en día. ${ }^{73}$

\section{Diócesis de Almería.}

Protestantes. En esta diócesis todavía no ha penetrado el protestantismo, (f. 99) o al menos una invasión de esta secta no se nota. Se intentó en diversas ocasiones introducirlo en pueblos limítrofes a Murcia, como Pulpí, por los protestantes de Águilas (Murcia) que es o ha sido un centro de protestantismo y podría temerse que aquello que no se ha conseguido hasta ahora se pueda lograr en seguida. En el presente, en la diócesis, protestantes pueden ser algunos di-

\footnotetext{
72 Informe del obispo de Urgel, Justino Guitart Vilardebó. Urgel, 11 abril 1930, en ASV, Arch. Nunz. Madrid, busta 848, fasc. 1, n. 55, ff. 172.

${ }^{73}$ Informe del obispo de Zamora, Manuel Arce Ochotorena. Zamora, 6 abril 1930, en ASV, Arch. Nunz. Madrid, busta 848, fasc. 1, n. 60, ff. 168-169.

Hispania Sacra, LXIII

127, enero-junio 2011, 305-371, ISSN: 0018-215-X
} 
rectores de Compañías Extranjeras, pero no hacen propaganda y se han tomado todas las medidas de precaución para que la diócesis se conserve inmune de este mal. De lo que más se duele el Obispo es que hay muchos indiferentes y fríos, y que no han sido totalmente extirpados el teosofismo y el espiritismo, aunque sus errores hayan sido denunciados en una reciente carta pastoral. A estos males hay que añadir aquél de la masonería que desde hace mucho tiempo se ha establecido y trabaja en Alhama y en otros pueblos que no pertenecen a Almería, si bien en esta ciudad haya alguna cosa..$^{74}$

\section{Diócesis de Ciudad Rodrigo.}

El Sr. Obispo en su informe declara: 1. Gracias a Dios no hay ningún protestante de nacionalidad española. 2. En el pueblo de Alberguería de Argañán los directores de la mina son alemanes y se cree que sean protestantes, pero no hacen propaganda $(f .100)$ y por esto el pueblo ignora la religión que estos extranjeros profesan. 3. En el pueblo de Navasfrías van ocasionalmente a visitar las minas súbditos ingleses y alemanes que se supone que son protestantes. Consta que un español de Espeja, originario de la diócesis o residente en Argentina, suele mandar folletos de propaganda protestante, pero sin ninguna eficacia. ${ }^{75}$

\section{Diócesis de Coria.}

El Sr. Obispo refiere que en ninguna parroquia de la diócesis existen centros de propaganda protestante ni siquiera la mínima práctica de ello, sea de parte de los españoles como de los extranjeros, ni en público, ni en privado, y que no se conocen ni siquiera ciertos folletos de doctrina protestante que en otras regiones se suelen mandar por correo. ${ }^{76}$

\section{Diócesis de Cuenca.}

El Sr. Obispo declara que, hechas las necesarias investigaciones, resulta que en la diócesis no existen protestantes españoles ni extranjeros, ni hay capillas, ni escuelas, asociaciones, ni pastores protestantes en ninguna parroquia. La propaganda como mucho se reduce a la venta de Biblias protestantes que no hacen ningún prosélito. Cree que las medidas que se deben $(f .101)$ actualmente tomar se han de reducir a que los sacerdotes que se dedican al cuidado de las almas avisen a los propios fieles que se abstengan de comprar Biblias u otro gé-

\footnotetext{
${ }^{74}$ Informe del obispo de Almería, Bernardo Martínez Noval. Almería, 1 abril 1930, en ASV, Arch. Nunz. Madrid, busta 848, fasc. 1, n. 1, ff. 6-7.

75 Informe del administrador apostólico de Ciudad Rodrigo, Manuel López Arana. Ciudad Rodrigo, 9 abril 1930, en ASV, Arch. Nunz. Madrid, busta 848, fasc. 1, n. 13, ff. 49.

76 Informe del obispo de Coria, Dionisio Moreno Barrios. Coria, 8 junio 1930, en ASV, Arch. Nunz. Madrid, busta 848, fasc. 1, n. 15, ff. 53-55.
} 
nero de publicaciones que vinieran ofrecidas a ellos de personas desconocidas y que en el caso de que las acepten las muestren a los sacerdotes para que las examinen. ${ }^{77}$

\section{Diócesis de Barbastro.}

El Sr. Obispo en su informe dice que sólo le consta de la presencia en diócesis de dos protestantes: uno de ellos volverá del servicio militar pervertido por un sargento, y otro díscolo y vividor que habitaba en una casa de campaña. Se intenta expulsarlo, no se sabe si lo han conseguido. ${ }^{78}$

\section{Archidiócesis de Burgos.}

El Sr. Arzobispo dice que después de haber examinados los informes anuales de los Reverendos Arciprestes y haber asumido informaciones, le resulta para gloria de Dios, que si en el pasado, por circunstancias especiales de extranjeros venidos a trabajar en las ferroviarias o por propaganda hubo algunos prosélitos y también algún salón con aspecto de capilla en cualquier localidad, (f. 102) hoy no hay ni locales, ni pastores, ni adeptos de ninguna de las diversas sectas o confesiones en las que se divide el protestantismo. Allí podría haber indiferentes, pero todos son católicos apostólicos romanos. ${ }^{79}$

\section{Diócesis de Huesca.}

Desde hace 25 años hay siete $\mathrm{u}$ ocho protestantes españoles en Lalueza, no tienen capilla ni siquiera escuelas, asociaciones o fundaciones, ni hacen propaganda. Se dice que se ocupa de ellos un pastor que reside en Zaragoza, que es aquél que suele intervenir cuando muere algún adulto. ${ }^{80}$

\section{Diócesis de Ibiza.}

En esta diócesis no hay protestantismo ni propaganda organizada. Si alguna cosa se sabe del protestantismo es por causa de algún extranjero inglés o alemán que está de paso por unos pocos días, sin que la gente dé importancia al hecho. De los pocos ingleses que pasan el invierno en la isla los más conocidos son buenos católicos, e incluso fervorosos. La propaganda que se hace se redu-

77 Informe del obispo de Cuenca, Cruz La Plana y Laguna. Cuenca, 30 abril 1930, en ASV, Arch. Nunz. Madrid, busta 848, fasc. 1, n. 16, f. 56.

${ }^{78}$ Informe del obispo de Barbastro, Nicanor Mutiloa e Irurita. Barbastro, 3 abril 1930, en ASV, Arch. Nunz. Madrid, busta 848, fasc. 1, n. 5, f. 19.

79 Informe del arzobispo de Burgos, Manuel de Castro y Alonso. Burgos, 25 marzo 1930, en ASV, Arch. Nunz. Madrid, busta 848, fasc. 1, n. 7, f. 29.

${ }^{80}$ Informe del obispo de Huesca, Fr. Mateo Colom Canals, OSA. Huesca, 8 abril 1930, en ASV, Arch. Nunz. Madrid, busta 848, fasc. 1, n. 20, f. 65.

Hispania Sacra, LXIII

127, enero-junio 2011, 305-371, ISSN: 0018-215-X 
ce a opúsculos y libros mandados desde Madrid a las librerías de Ibiza, pero apenas los libros se reciben, los destruyen.

(f. 103) En los alrededores de Ibiza hay un pastor protestante nativo de un pueblo de la isla, Argel, y el año pasado siendo preguntado por los habitantes de este pueblo sobre su exacto estado en el cumplimiento de sus deberes religiosos, estos amenazaron con llamar a dicho pastor; pero bastó una simple indicación del ejemplar católico Don Pedro Llosas Badia, entonces Gobernador de las Baleares, para que no se hablase más del asunto, y se dieran medidas para que se guardaran bien de hablar del llamado dicho Ministro y de permitirle la entrada en la isla. ${ }^{81}$

\section{Diócesis de Osma.}

En 1904 se estableció en la ciudad de Soria un pequeño núcleo de protestantes, que instalaron una capilla en una habitación de una casa privada, pero no encontraron ambiente favorable y marcharon en 1905 sin hacer ningún prosélito. En el pueblo de Roa de Duero (Burgos) y su distrito, en estos últimos años se ha notado la presencia de algunos individuos protestantes procedentes de Valladolid y de Tudela del Duero que intentaron hacer propaganda, pero con la ayuda de las autoridades civiles de las respectivas localidades, consiguieron hacerles desistir. Actualmente no se sabe que exista en la diócesis algún protestante $(f .104)$ y mucho menos algún centro de la secta. ${ }^{82}$

\section{Diócesis de Palencia.}

En esta diócesis, tanto en la ciudad como en los pueblos, no se ve ningún protestante. Alguna vez, alguna persona, no del lugar, de nacionalidad española, ha distribuido pancartas y folletos de propaganda protestante, pero con la ayuda de la autoridad se ha podido impedir que este inconveniente continuara, antes de que allí hubiera adeptos. ${ }^{83}$

\section{Diócesis de Pamplona.}

Desde que, hace cuarenta años atrás, se hace una propaganda activa en la ciudad de Pamplona, no se tiene noticia que existan en la diócesis protestantes o que se haga propaganda. Allí hay algún individuo aislado de nacionalidad extranjera, director de fábricas o de laboratorios que no obstante no sólo no hace propaganda, sino que incluso se guarda de hacer muestra pública de sus creen-

\footnotetext{
${ }^{81}$ Informe del obispo de Selimbria y administrador apostólico de Ibiza, José. Ibiza, 9 abril 1930, en ASV, Arch. Nunz. Madrid, busta 848, fasc. 1, n. 21, f. 66.

82 Informe del obispo de Osma, Miguel de los Santos Díaz y Gómara. Osma, 4 abril 1930, en ASV, Arch. Nunz. Madrid, busta 848, fasc. 1, n. 34, f. 114.

83 Informe del obispo de Palencia, Agustín Parrado García. Palencia, 27 marzo 1930, en ASV, Arch. Nunz. Madrid, busta 848, fasc. 1, n. 36, ff. 120.
} 
cias en público. Incluso si alguno de estos protestantes ocultos se casa en la diócesis, se convierte al catolicismo. ${ }^{84}$

\section{Diócesis de Segovia.}

(f. 105) En esta diócesis no hay más que un protestante inglés, residente en la parroquia de Bernardos, donde posee algunas minas. No sólo no hace propaganda, sino que incluso se muestra bien dispuesto hacia los sacerdotes y el culto católico. En la parroquia de Navares de Enmedio se ha comenzado recientemente alguna propaganda por medio de los folletos y las revistas que envía un pastor protestante casado en Barcelona con una mujer de dicha parroquia. El párroco, sin embargo, está advertido y contrarresta con celo esta propaganda. ${ }^{85}$

\section{Diócesis de Sigüenza.}

En esta diócesis no existe ningún centro protestante y no hay ni siquiera capillas, escuelas, pastores y fundaciones de ninguna clase. Puede ser que en una media docena de pueblos próximos a la ferroviaria exista allí algún propagandista, pero su acción permanece limitada a los ferroviarios y quizás a alguno que escucha más por curiosidad que por otro motivo. En 1926 dos desconocidos sorprendieron al alcalde de Radona diciéndole que deseaban dar algunas conferencias, sin indicar el argumento y que por esto deseaban que reuniese al pueblo. El alcalde $(f .106)$ accedió a sus deseos y entonces el conferenciante declaró que había venido para implantar el protestantismo que había de darles muchas ventajas. El párroco que había ido a aquel encuentro, ignorando de qué se trataba, informó al Obispo y éste al domingo siguiente se acercó a dicho pueblo con el Gobernador. Allí se celebró una función de reparación y el Obispo predicó contra los errores del protestantismo, dirigiéndose de modo particular a la autoridad reprobándole el haber permitido que se diera dicha conferencia en el Ayuntamiento. El alcalde leyó delante del pueblo la profesión de fe. El Gobernador también habló al pueblo, y especialmente al alcalde, reprobándole el error en que había caído. Le perdonó luego, a petición del Obispo, una multa de doscientas pesetas que le había impuesto, y el incidente tuvo una solución feliz. ${ }^{86}$

\section{Diócesis de Solsona.}

También en esta diócesis no hay protestantes. Se ha hecho una diligente investigación en los lugares donde se podía sospechar que hubiera, esto es, en los

\footnotetext{
${ }^{84}$ Informe del obispo de Pamplona, Tomás Muniz y Pablos. Pamplona, 23 marzo 1930, en ASV, Arch. Nunz. Madrid, busta 848, fasc. 1, n. 37, f. 122.

85 Informe del obispo de Segovia, Luciano Pérez Platero. Segovia, 14 mayo 1930, en ASV, Arch. Nunz. Madrid, busta 848, fasc. 1, n. 43, f. 132.

${ }^{86}$ Informe del obispo de Sigüenza, Eustaquio Nieto y Martín. Sigüenza, 11 abril 1930, en ASV, Arch. Nunz. Madrid, busta 848, fasc. 1, n. 45, ff. 138-139. 
bancos mineros, pero el resultado ha sido la confirmación de que no hay protestantes. (f. 107) Alguna vez llegan a este centro folletos de propaganda o Biblias protestantes, pero ninguno les hace verdaderamente caso. ${ }^{87}$

\section{Diócesis de Guadix.}

Dice el Sr. Obispo que por misericordia de Dios no hay protestantes que tengan domicilio en la diócesis. No se hace propaganda propiamente dicha. Alguna vez pasa por los diversos pueblos algún agente de la «Editorial Bíblica» que vende evangelios a gente simple, la cual apenas conoce el origen enseguida los entrega al párroco. Este comercio se ejercita furtivamente, porque la autoridad civil lo prohíbe. 88

\section{Diócesis de Teruel.}

El Vicario General de la Diócesis por orden del Sr. Obispo enfermo, comunica que en la diócesis no hay protestantes, porque de los dos que había en el pueblo, uno de ellos ha muerto reconciliado con la Iglesia y el otro ha depuesto su actitud..$^{89}$

\section{Diócesis de Tudela.}

No hay en esta diócesis protestantes. Había uno ( $f$. 108) en Tudela, de profesión mecánico, pero el año pasado fue bautizado solemnemente y contrajo matrimonio en el seno de la Iglesia Católica. De vez en cuando, en dicha ciudad se hace alguna propaganda de libros y de folletos; pero los fieles las han entregado siempre a sus respectivos párrocos para que los destruyan, o bien, una vez advertidos, los han destruido ellos mismos. .90

\section{Jurisdicción Castrense.}

El Excmo. Patriarca de las Indias Occidentales, Vicario General Castrense, dice que no le resulta que en su jurisdicción se propaguen las doctrinas protestantes entre los soldados dentro o fuera de los cuarteles. Sólo parece que en el pasado mes de abril se haya hecho propaganda teosofista entre los legionarios

${ }^{87}$ Informe del obispo de Solsona, Valentín Comellas Santamaría. Solsona, 14 mayo 1930, en ASV, Arch. Nunz. Madrid, busta 848, fasc. 1, n. 46, f. 140.

88 Informe del obispo de Guadix, Manuel Medina Olmos. Guadix, s.f., en ASV, Arch. Nunz. Madrid, busta 848, fasc. 1, n. 19, ff. 63-67.

${ }^{89}$ Informe del obispo de Teruel y administrador apostólico de Albarracín, Salustiano Sánchez. Teruel, 8 junio 1930, en ASV, Arch. Nunz. Madrid, busta 848, fasc. 1, n. 50, f. 150.

90 Informe del obispo de Tarazona y administrador apostólico de Tudela, Isidro Gomá y Tomás. Tudela, 1 abril 1930, en ASV, Arch. Nunz. Madrid, busta 848, fasc. 1, n. 53, f. 158. 
de África, y en el mes de mayo del año pasado, algún capellán castrense de la guarnición de Alicante se comprometió tomando parte activa en la propaganda de carácter espiritista o teosofista.

\section{Observaciones.}

Datos estadísticos. Las respuestas dadas por los Reverendísimos Ordinarios $(f .109)$ a la circular de la Nunciatura sobre el protestantismo en España, en varios casos no son dadas con mucho cuidado, y por lo que se refiere a los centros principales de Madrid y Barcelona son dadas así a la ligera con lo que no se consigue ni siquiera conjeturar el número aproximado de los protestantes, dato éste que sería ciertamente el más importante. Las estadísticas ofrecidas por el Gobierno dan 750 protestantes en Madrid y fijan en diez el número de escuelas y en 729 el número de los alumnos. Para Barcelona las cifras oficiales gubernamentales dan el número de 1.075 protestantes en la ciudad, y hacen ascender a ocho el número de las escuelas y a 916 aquél de los alumnos.

Estas cifras van añadidas a aquéllas suministradas por los Prelados de las otras diócesis que en conjunto son las siguientes: individuos, 7.887; familias, 255. Fijando una media de cuatro personas por cada familia resulta un total de 1.020 individuos, que unidos a los 7.887 aislados, no comprendidos aquellos indicados por Barcelona y Madrid según las estadísticas gubernamentales, dan un total de 8.907 protestantes. Si a éstos se añaden también los 750 de Madrid y los 1.075 de Barcelona, computados en el anterior cálculo, se tiene un total definitivo de 10.732 protestantes. (f. 110) Esta cifra es ligeramente inferior a aquélla fijada por el Gobierno en 11.227 protestantes, y sensiblemente inferior a aquélla que da el escritor católico, investigador de la ciencia estadística, Don Eduardo Navarro Salvador, que después de varios estudios prolijos, fijó en quince mil el número de protestantes en España.

La cifra ofrecida por los prelados es la más optimista, evidentemente por la insuficiencia de los datos. El número por sí mismo no sería muy alarmante, porque se trata del resultado de más de sesenta años, al menos de asidua propaganda. Además se ha de tener presente que gran parte de los protestantes son extranjeros emigrados aquí, protestantes de origen, y que no pocos españoles apóstatas se han pasado al protestantismo por haber emigrado a otros países. El fracaso es evidente, y se ha confirmado cuanto decía Balmes, esto es, que el protestantismo no encuentra aquí ambiente propicio. El daño mayor que puede hacer el protestantismo en España, con su propaganda, es aquél de confundir las ideas en el campo religioso, y de crear por tanto confusión y producir indiferencia religiosa que algún prelado lamenta como el mal mayor. 
Resumiendo los otros datos estadísticos, se tienen: pastores protestantes, 86; capillas, 98; escuelas, 74; alumnos que las frecuentan, 2.654. (f. 111) Estas últimas cifras, según los datos ofrecidos por los Ordinarios, deben ser ciertamente aumentadas, y esto parece claro confrontando los datos ofrecidos por el Gobierno, que sólo por Madrid y por Barcelona asignan respectivamente, por aquello que por ejemplo se refiere al número de alumnos, 729 para la primera ciudad, y 916 para la segunda, con un total de 1.645 alumnos para estas dos ciudades solamente. Creo que más conformes con la verdad son los datos del Gobierno que dan 145 capillas, 78 escuelas y 5.830 alumnos.

\section{Causas del protestantismo.}

Las causas del protestantismo hay que buscarlas, desde el momento en que aparecen los datos ofrecidos, especialmente en la inmigración de los pueblos protestantes, y este mal siempre irá a más, aumentando, como aquél de la emigración a naciones católicas. Otra causa es la propaganda que se hace con el dinero, con las escuelas, con publicaciones, especialmente de carácter popular, y en algún caso con la asistencia sanitaria.

Por lo que se refiere a la propaganda intelectual, lamentablemente es constante, comparada incluso con el movimiento católico, literario, social y político de la nación, no llega a ocupar ningún puesto entre los elementos de la cultura. Esto explica como no ha surgido una situación de verdadera polémica doctrinal, y que los católicos no concedan a los protestantes beligerancia alguna, $(f .112)$ sino que se limitan al desprecio.

\section{Medios para contrarrestar la propaganda.}

Ningún medio podrá naturalmente detener los movimientos de las emigraciones e inmigraciones que tanto favorecen al protestantismo. Estos dos movimientos, con aquel comercial e industrial, formarán incluso un peligro siempre mayor. Lo que únicamente se puede hacer, es recomendar a los párrocos que de mantenerse en contacto con sus parroquianos emigrados, si no hay otro en medio de sus familias. Contra las otras causas del protestantismo, más allá de la oración, que es siempre el medio más eficaz, según mi humilde parecer, se podrían adoptar los siguientes remedios:

a) Aprovechar las profundas raíces que en España tienen la devoción al Papa y a la Santísima Virgen.

b) Habiendo caído en España la unidad católica y no pudiendo por esto hacer recurso, en todos los casos, por los medios legales, es necesario por lo menos invocar aquéllos que vienen de la interpretación estricta de aquella tolerancia religiosa que ha sido concedida, y rechazar la tendencia a la libertad religiosa, haciendo así que las autoridades intervengan donde la tolerancia se 
convierte en libertad, y la libertad en licencia. ( $f$. 113) Como se sigue de los informes de los diversos prelados, en la gran mayoría de los casos las autoridades prestan su válido apoyo. Cuando éstas no son sinceramente católicas, todos los pretextos legales son buenos para dejar libres a los protestantes; pero cuando son verdaderamente católicas, pueden muy bien volver imposible la propaganda, y por tanto la existencia de los protestantes.

c) Misiones en los puntos donde hay protestantes, predicadas por sacerdotes o religiosos preparados para esta clase de lucha, que sepan combatir el protestantismo e ilustrar los orígenes inmorales en muchos casos. En España no son necesarias grandes disertaciones porque el pueblo tiene como error el protestantismo, dado su tradicional amor a la Iglesia Católica y a la Santa Sede; y por cuanto se refiere al elemento culto, éste ya ha juzgado al protestantismo.

d) Procurar que los niños encuentren en nuestras escuelas las ventajas didácticas y económicas que ofrecen los protestantes. En algunos pueblos los niños van a la escuela protestante porque en el pueblo no hay escuela nacional. Éste es el caso de abrir aquí una escuela parroquial rápidamente, y luego obligar al Ayuntamiento a seguir las disposiciones del Real Decreto del 23 de diciembre de 1921 que impone construcciones de escuelas, a las que el Estado contribuya (f. 114) con el ochenta por ciento.

e) Valerse de las asociaciones católicas para hacer el vacío alrededor de los protestantes. Las asociaciones femeninas podrían penetrar en las familias, cuyos hijos van a las escuelas protestantes y disuadirlos de mandarlos. Por otra parte, las asociaciones católicas de caridad podrían tener presentes las familias objeto de todo cuidado sanitario de parte de los protestantes, y sustituirlos a ellos en la obra de asistencia.

f) Instituir algún órgano especial para vigilar los movimientos de los protestantes. En la diócesis de Madrid, según el informe del señor Obispo, se ha instituido una Junta presidida por un Canónigo de la Catedral; una cosa similar se podría hacer en toda la nación, pero exigiendo una mayor actividad, porque de esta Junta de Madrid no se oye nunca hablar, y no debe ser muy solvente porque, como yo he anotado arriba, los datos enviados por el Obispo de Madrid son muy deficientes.

g) En los lugares donde se envían folletos de carácter protestante, impedir cuanto se pueda la difusión, y donde no se consiga hacerlo, difundir folletos en los que se rebatan los errores protestantes, como aquéllos que Padre De Mandato difunde en Roma con tanto éxito del 1890 al 1900.

(f. 115) Más allá de estas normas generales, otras pueden ser, dadas las circunstancias del tiempo y del lugar que un trabajo de obligada y asidua vigilancia puede indicar. 
El Santo Padre luego, inspirado por su celo apostólico, podrá añadir observaciones y consejos de fuerza sobrenatural y decisivos, y yo estaré feliz de poder llevárselos pronto a estos celosos Obispos Españoles.

Inclinado le beso la Sagrada Púrpura, y tengo el honor de repetirme con los sentidos de la profunda veneración de Vuestra Reverendísima Eminencia, humildísima Servidor.

Federico, Arzobispo de Lepanto, Nuncio Apostólico».91

${ }^{91}$ Despacho n. 4896 del nuncio al secretario de Estado. Madrid, 6 febrero 1931, en ASV, A.E.S., Stato Spagna, IV periodo, pos. 790, fasc. 146, anno 1931, ff. 1-115. 